Lending relationships and credit rationing: the impact of securitization

Santiago Carbó-Valverde, Hans Degryse, Francisco Rodriguez-Fernandez

DEPARTMENT OF ACCOUNTANCY, FINANCE AND INSURANCE (AFI) 


\title{
Lending relationships and credit rationing: the impact of securitization
}

\author{
By \\ Santiago Carbó-Valverde \\ Bangor Business School and FUNCAS \\ Hen Goleg, College Road, Bangor, LL57 2DG, Gwynedd, UK \\ E-mail: s.carbo-valverde@bangor.ac.uk \\ Hans Degryse \\ KU Leuven, Tilburg University and CEPR \\ Naamsestraat 69, BE-3000 Leuven, Belgium \\ E-mail: hans.degryse@kuleuven.be \\ Francisco Rodriguez-Fernandez \\ University of Granada and FUNCAS \\ Departamento de Teoría e Historia Económica \\ Facultad de CC. Económicas y Empresariales,Campus Cartuja s/n, 18071 Granada, Spain \\ E-mail: franrod@ugr.es
}

\begin{abstract}
$\underline{\text { Abstract }}$
Banks have been heavily involved in securitization. We study whether the involvedness of a firm's main bank into different types of securitization activity - asset backed securities (ABS) and covered bonds - influences credit supply before and during the 2007-8 financial crisis. Both types of securitization allow the bank to generate liquidity. To the extent that ABS activity lowers lending standards in normal times, banks with more ABS activity may reduce their lending more in crisis times as an ex-post effect of a previously higher risk adoption. Employing a disequilibrium model to identify credit rationing, we find that a longer relationship with a firm's main bank considerable improve credit supply. In general, we find that a relationship with a bank that is more involved in securitization activities relaxes credit constraints in normal periods. In contrast, while a relationship with a firm's main bank that issues covered bonds reduces credit rationing during crisis periods, the issuance of asset backed securities by a firm's main bank aggravates these firm's credit rationing in crisis periods.
\end{abstract}

\section{JEL-classification: G21}

Keywords: lending relationships, financial crisis, securitization.

Acknowledgements: Financial support from the Spanish Savings Banks Foundation (FUNCAS), MICINN-FEDER ECO2011-27954 and Junta de Andalucía and P08-SEJ-03781 (Excellence Groups) is gratefully acknowledged. We would like to express our gratitude for the comments provided on this paper by Oscar Arce, Alessandro Beber, Martin Brown, Max Bruche, Barbara Casu, Evren Damar, John V. Duca, Daniela Fabbri, John Goddard, Pablo Hernandez de Cos, Jose Liberti, German Lopez Espinosa, Phil Molyneux, Antonio Moreno, Lars Norden, Alberto Pozzolo, Lucio Sarno, Klaus Schaeck, Sascha Steffen, Simone Westerfeld, as well as seminar participants at Bangor Business School, Cass Business School, the 2012 Bank of Spain-CNMV workshop on SME Finance (Madrid), the 2012 MoFiR Workshop on Banking (Ancona), the 2012 FIRS conference (Minneapolis), the 2012 FMA European Conference (Istanbul), and the 2012 FMA Asia conference (Phuket). 


\section{Introduction and motivation}

The global financial crisis that started in 2007 and the ensuing flight away from risk have affected credit flows towards various groups of firms to different degrees. Firms relying heavily on bank credit such as small and medium sized enterprises (SMEs) are particularly vulnerable to the credit crunch and potential supply side effects induced by the banking system. At the same time, SMEs typically benefit from strong bank-firm relationships, which may help mitigating these supply side effects. We investigate how the activity of a firm's main bank in different types of securitization ${ }^{1}-$ Asset and Mortgage Backed Securities (for short, ABS) and covered bonds - affect a firm's financing constraints during normal periods and during crisis periods. The 20072009 worldwide financial crisis provides an opportunity to study the role of lending relationships and these banks' involvedness in securitization activities on credit availability.

We focus on how securitization activities of a firm's main bank impacts credit availability to that firm during normal periods and crisis periods. In particular, we contrast the impacts of two different forms of securitization - ABS versus covered bonds - and study how they interact with relationship lending before and during the crisis. ABS and covered bonds are both backed by a pool of mortgages and put into a ring fence. With covered bonds, the mortgages remain on the issuing bank's balance sheet and defaulting mortgages are replaced by new ones. ABS in contrast allows for risk transfer in the absence of credit guarantees (see Carbo et al. (2012)), or induce regulatory arbitrage when credit guarantees are offered to the special purpose vehicle investors and allow to concentrate risk (see Acharya et al. (2011)). Both covered bonds

\footnotetext{
${ }^{1}$ We employ a broad definition of securitization that includes both on-balance sheet securitization (covered bonds) and off-balance sheet securitization (Asset and Mortgage Backed Securities).
} 
and ABS generate liquidity in normal times. In crisis times, ABS suffered from reduced liquidity access stemming from previously higher risk adoption. We address whether firms with more intense bank-firm relationships are better hedged against this supply side effect than otherwise similar firms. To study the impact of these different forms of securitization, we combine several unique data sets on Spanish firms, their firm-bank relationships, and their banks' securitization activity.

The impact of different forms of securitization on SME financing is of great concern to governments as SMEs are the backbone of OECD economies accounting for up to $97 \%$ of all firms, between 40 and $60 \%$ of GDP, and up to $70 \%$ of employment (and even higher percentages in non OECD countries). Our results are relevant for both practitioners and policy makers. Our insights may help in designing financial regulation on bank liquidity and bank securitization activities in order to dampen the impact on credit rationing. For example, while covered bonds have been intensively issued in Europe, they were not in the US as the lack of domestic legislation prevented US banks from tapping this funding source. ${ }^{2}$ The US covered bond act of 2011 changed this perspective. Our results have implications for the ongoing changes in legislation.

Our main findings can be summarized as follows. First, firms whose main bank is more involved in securitization (ABS or covered bonds) enjoy lower credit constraints in normal periods (i.e., in the run up to the crisis). Second, we study heterogeneity within securitization activity by investigating the impact of different types of securitization - ABS and covered bonds - on credit rationing. While both types of securitization reduce credit constraints in normal periods, a firm's main bank issuing ABS aggravates credit rationing in crisis periods. This shows that securitization

\footnotetext{
${ }^{2}$ Exceptions are Bank of America and Washington Mutual which issued the first US covered bonds in 2006.
} 
generates different supply side effects which depend on whether we are in normal or crisis periods and on the type of securitization.

Our paper is related to two strands of literature. First, it is related to empirical work on the causes and consequences of securitization (see e.g., Mian and Sufi (2009); Keys et al. (2010); Panetta and Pozzolo (2010), or Dell'Ariccia et al. (2012)). Securitization may stimulate loan supply by increasing the liquidity of banks' balance sheets and improving a banks' risk absorption capacity (see e.g., Wagner and Marsh (2006) or Duffie (2007)). Initial empirical work shows that selling of loans does not hamper the bank-firm relationship (Drucker and Puri (2009)), and that the use of credit derivatives enhances a bank's loan supply (Hirtle (2007)). Nini (2008) shows that the growth of non-bank institutional investors in the market for bank loans provided a significant increase in the supply of credit, and Shivdasani and Wang (2011) demonstrate that the securitization market fuelled the leverage buyout market. Our paper is closest related to studies on the impact of securitization on bank's lending behaviour (see e.g., Goderis et al. (2007), Jiménez et al. (2010) or Carbó et al. (2011)). Goderis et al. (2007) find that banks who are active in securitization exhibit a larger loan growth than banks not being active in securitization. We improve upon their work as we employ bank-firm level lending relationship information and their main bank's activity in securitization to study how different types of securitization affects credit constraints at the firm level. Jiménez et al. (2010), employing detailed bank-firm level data from the Spanish credit registry, find that banks with more securitizable assets make more loans available to firms. However, there is a substantial crowding out effect taking place as this expansion crowds out other bank loans to the same firm. They conclude that the impact of securitization is close to zero due to the crowding out of existing bank credit. Their identification strategy relies on employing firm*time fixed 
effects to absorb credit demand shocks, allowing comparing within the same firm the impact of bank credit supply shocks. This implies that they consider firms with at least two bank relationships which may be a restriction as many firms have one bank only and single relationship firms may be the ones where the supply side effects are most pronounced (see e.g., Degryse et al. (2011) showing that shocks stemming from bank mergers are most severe for single relationship firms). We study how securitization activity of the firm's main bank impacts credit supply and credit rationing also for single relationship firms. ${ }^{3}$ During stress periods, however, banks relying on securitization may face additional liquidity or capital constraints reducing their willingness to provide loans. Irani (2012) for example investigates the impact of securitization on credit availability during the financial crisis and finds that banks with greater exposure to the securitization market are less willing to provide lines of credit. While Irani (2012) analyzes publicly listed US firms, we focus on SMEs.

A second strand of related papers addresses the question on how relationship banking affects credit availability in normal times and in crisis periods. Most studies find that relationship borrowers (longer duration, wider scope, geographically close banks) have better access to credit (see e.g., Petersen and Rajan (1994), or Degryse et al. (2009) for a comprehensive overview). Other papers study the impacts of bank distress on borrowing firms and the role of relationships. The closest to our work are recent papers that look into the question whether the US financial crisis spurred a supply side effect. Puri, Rocholl and Steffen (2011), for example, employ loan application data at German savings banks in the period 2006-2008. They investigate whether savings banks

\footnotetext{
${ }^{3}$ Carbó et al. (2011) analyze the deterioration of credit quality in Spain considering rating changes in Asset and Mortgage Backed securitized deals. Their results suggest that loan growth significantly affects loan performance with a lag of at least two years while loan performance is found to explain rating changes with a lag of four quarters. They also find that, although Asset and Mortgage Backed securitized products are supposed to ensure remoteness from their originating bank, bank characteristics (in particular, observed solvency, cash flow generation and cost efficiency) affect ratings considerably.
} 
which are exposed to shocks from Landesbanken (whom they own) stemming from the US, behave differently than non-exposed savings banks, i.e. who own Landesbanken without exposure to the US financial crisis. They find evidence consistent with a supply side effect as affected banks reject substantially more loan applications than nonaffected banks. Furthermore, bank relationships mitigate supply side effects as firms with longer relationships are less likely to be rejected even when their bank is exposed to a financial shock. We contribute to this literature by investigating how a firm's main bank's previous access to additional liquidity impacts credit supply when the securitization market dries up. ${ }^{4}$

The remainder of the paper is organized as follows. The second section provides the data and methodology. Section 3 presents the results of our analysis. Section 4 concludes.

\section{Data and methodology}

\subsection{Data}

We combine different data sources for our empirical analysis. The primary source of firm-level information is the SABI (Sistema de Análisis de Balances Ibéricos) database by Bureau Van Dijk. SABI includes accounting and financial information on more than 700,000 Spanish firms since 1990. Firms are included in the database when they have at least one employee. SABI includes information on headquarters' location, date of constitution, firm industry, number of employees, legal form of the business, whether the firm is quoted on a stock exchange and, most importantly for our purposes,

\footnotetext{
${ }^{4}$ Petersen and Rajan (1994) employed data on firms' reliance on trade credit to study the impact of relationship lending. They found that firms with longer bank-firm relationships were less likely to employ costly trade credit. We employ a disequilibrium model as recently the assumption that trade credit is more costly than bank credit has been subjected to criticism (Burkart et al. (2011)).
} 
the name of the bank(s) with whom the firm operates. The information on bank-firm relationships is retrieved every year.

Our final sample covers 56,752 firms over the period 1993-2008, which represents around $7 \%$ of total firms in Spain on average over the sample period ${ }^{5}$. Due to entry and exit of the firms, the panel is unbalanced and the number of firm-year observations is 326,332 . If both consolidated and non-consolidated accounts are available, we choose the consolidated ones.

The banks' financial statement information is obtained from the balance sheet and income statements data reported by individual commercial and savings banks to the Spanish Banking Association (AEB) and the Spanish Confederation of Savings Banks (CECA). As for the securitization data, they have been obtained from the Dealogic database.

\subsection{Hypotheses}

To study the impact of banks' activities in different types of securitization (ABS and covered bonds), we formulate two hypotheses each covering one type of securitization. The two hypotheses are based on the common and differential characteristics of ABS and covered bonds. Both types of securitization allow banks to turn traditionally illiquid claims into marketable securities providing them with more liquidity. This additional liquidity may increase banks' willingness to lend. In the absence of credit guarantees provided by the issuing bank to the special purpose vehicle, ABS allow for risk transfer (see Carbo et al. (2012)). ABS induce regulatory arbitrage when credit guarantees are offered to the special purpose vehicle investors and allow to concentrate risk (see Acharya et al. (2011)). Keys, Seru and Vig (2011) and Keys,

\footnotetext{
${ }^{5}$ All territories in Spain are represented with a coverage of at least $6 \%$ of total firms in each territory.
} 
Mukherjee, Seru and Vig (2010) for example show that more securitization implied lower lending standards in the subprime market in the U.S. Maddaloni and Peydró (2011) show that the softening of lending standards both in the U.S. and Europe following low short-term interest rates was greater with more securitization activity. Kara, Marques and Ongena (2011) show that originating banks more active on the securitization market are also more aggressive on their loan pricing in the wholesale market. These papers therefore argue that greater securitization activity induced more risk-taking by banks. To the extent that ABS activity lowers lending standards in normal times, banks with more ABS activity may reduce their lending more in crisis times as an ex-post effect of a previously higher risk adoption (see also Irani (2012)).

The underlying assets of covered bonds may be of higher quality as the issuer continues to absorb default risk and prepayment risk of the pool. Therefore, issuance of covered bonds by firms' main banks may not have detrimental impacts on firm's access to credit also in crisis times. In sum, while both types of securitization provide banks with more liquidity in normal times, ABS are more subject to agency problems and increased risk taking (see also Carbó et al. (2011)).

This leads us to formulate the following two hypotheses:

Hypothesis 1: Firms borrowing from banks issuing (to a greater degree) ABS enjoy a greater credit supply in normal times but are more likely to become credit rationed during financial crises.

Hypothesis 2: Firms borrowing from banks issuing (to a greater degree) covered bonds will enjoy a greater credit supply in normal times and are less likely to be credit rationed during financial crises. 


\subsection{Empirical Methodology and Specifications}

The test of our two hypotheses requires identifying constrained firms. In a seminal credit rationing paper, Stiglitz and Weiss (1981) show that loan markets in the presence of asymmetric information can be frequently characterized by a disequilibrium status. Although some accounting ratios can be relevant indicators of firm financing constraints, it is also possible to infer lending demand and availability and to estimate the probability of credit rationing from a disequilibrium model. From an econometric point of view, the main challenge associated with estimating the market model in disequilibrium is that one has to obtain estimators for the parameters of loan supply and demand functions using only observed volume of transactions in the loan market. As demand and supply for bank loans are typically not observed (see however Kirschenmann (2010), or Degryse, Ioannidou and von Schedvin (2012) for settings where credit supply is observed), a disequilibrium model can solve this problem, by assigning the observations either to the demand or the supply equation. Maddala and Nelson (1974) discuss the appropriate maximum likelihood method for this class of disequilibrium models, which has been used for empirical analysis of credit markets in different countries (see e.g. Sealey (1979); Perez (1998), Ogawa and Suzuki (2000); Atanasova and Wilson (2004); Steijvers (2008), or Carbó et al. (2009)).

We set up a model of bank loan demand by individual firms, allowing for the possibility that the firms cannot borrow as much as they would like. We follow Carbó et al. (2009) to measure constrained versus unconstrained firms; however, we augment their model to incorporate the role of bank-firm relationships and the different types of securitization activity of the main bank holding a relationship with the firm. A disequilibrium model with unknown sample separation, as described by Maddala (1980), is employed. The basic structure of the model consists of two reduced-form 
equations: a desired demand equation for bank loans and an availability equation that reflects the maximum amount of loans that banks are willing to lend. A third equation is a transaction equation. In this model, the realized loan outstanding is determined by the minimum of desired level and ceiling. The loan demand ( $\left.\operatorname{Loan}_{i t}^{d}\right)$, the maximum amount of credit available ( $\left.\operatorname{Loan}_{i t}^{s}\right)$ and the transaction equation $\left(\operatorname{Loan}_{i t}\right)$ of firm $i$ in period $t$ are:

$$
\begin{aligned}
& \operatorname{Loan}_{i t}^{d}=\beta_{0}^{d}+\beta_{1}^{d} \text { Activity }_{i t}^{d}+\beta_{2}^{d} \text { Substitutes }_{i t}+\beta_{3}^{d} \text { Cost }_{i t}+u_{i t}^{d} \\
& \operatorname{Loan}_{i t}^{s}=\beta_{0}^{s}+\beta_{1}^{s} \text { Collateral }_{i t}+\beta_{2}^{s} \text { Default risk }_{i t}+\beta_{3}^{s} \operatorname{Cost}_{i t}+u_{i t}^{s} \\
& \operatorname{Loan}_{i t}=\operatorname{Min}\left(\operatorname{Loan}_{i t}^{d}, \operatorname{Loan}_{i t}^{s}\right)
\end{aligned}
$$

The amount of bank credit demanded is modelled as a function of the level or the expansion of firm activity, firm size, other sources of capital that are substitutes to bank loans, and the cost of bank credit. The maximum amount of credit available to a firm is modelled as a function of the firm's collateral and default risk. All level variables are expressed in terms of ratios to reduce heteroscedasticity. As a common feature in disequilibrium models the size effect of (lagged) "total assets" in the demand equation above is estimated as part of the constant term. For consistency, the constant term is estimated as a coefficient of the reciprocal of total assets (the same logic is applied to the collateral effect of total assets and the constant term in the availability equation). Firm activity is represented by the level of sales over the one-year lagged total assets. Both firm production capacity (total assets) and sales are expected to increase (the level of) loan demand. Cash flow as a ratio of lagged total assets is used to control for the effect of substitute funds on the demand for bank loans and, therefore, the expected sign of this variable is negative. The cost of bank credit is expressed as the 
percentage point spread between the interest rate paid $^{6}$ by the firm and short-term prime rate and it is also expected to affect loan demand negatively ${ }^{7}$.

In the availability equation, a firm's "collateral" is proxied by the ratio of tangible fixed assets to lagged total assets and the expected sign is positive since the maximum amount supplied by a bank will increase with the level of collateral. We assume here that tangible assets are taken as collateral or, if not, are potentially attachable as collateral by the bank. We also include the age of the firm as a proxy of reputation and information availability on the firm. The Lerner index - the difference between banks' prices and marginal costs divided by prices- is included as an indicator of the banks' market power in the regions ${ }^{8}$ where the firm operates. Firms' default risk is measured by the ability to pay interest (proxied by the operating profit/interest ratio) and the ability to pay short-term debt (proxied by the current assets/current liabilities ratio). A high operating profit/interest ratio or a high current assets/current liabilities ratio indicates that the default risk is low. Therefore, we expect the collateral variable and the variables that indicate the ability to pay interest and short term debt to be positive. Both demand and availability equations contain regional GDP $(\log (G D P))$ to control for macroeconomic conditions across regional markets. We also include time dummies which further control for business cycle fluctuations as well as trends in ABS and covered bond issuance activities. They are not reported in the table for expositional reasons.

The simultaneous equations system in (1), (2) and (3) is estimated using full information maximum likelihood (FIML), as shown by Maddala and Nelson (1974).

\footnotetext{
${ }^{6}$ The "interest paid" was computed from the income statement. We divided it by bank loans outstanding. We implicitly assume that the year-end loan balance is roughly equal to the weighted average balance during the year.

${ }^{7}$ Since interest rates are central in this model, loan prices were alternatively introduced in levels instead or relative to short-term prime rate. The results remain statistically unaltered.

${ }^{8}$ See Table 1 for a detailed definition on how the Lerner index is computed for banks operating in various regions.
} 
The FIML routine employed also incorporates firm and bank fixed effects to account for unobservable firm-level and bank-level influences. Endogeneity is a potential concern in estimating these equations, particularly in the demand equation which regresses a quantity, on, among other things, the price of that quantity. Lagged values of the explanatory variables are used as instruments. This treatment eliminates perhaps the most obvious source of endogeneity, but, as is well understood, it does not eliminate all such sources if errors are correlated over time. Based upon the estimates of this system it is possible to compute the probability that loan demand exceeds credit availability, as shown in Gersovitz (1980) and, therefore, to classify the sample into constrained and unconstrained firms. Formally, a firm is defined as financially constrained in year $t$ if the probability that the desired amount of bank credit in year $t$ exceeds the maximum amount of credit available in the same year is greater than 0.5 . Hence, the probability that the firm will face a financial constraint in year $t$ is derived as follows:

$\operatorname{Pr}\left(\operatorname{loan}_{i t}^{d}>\operatorname{loan}_{i t}^{s}\right)=\operatorname{Pr}\left(X_{i t}^{d} \beta^{d}+u_{i t}^{d}>X_{i t}^{s} \beta^{s}+u_{i t}^{s}\right)=\Phi\left(\frac{X_{i t}^{d} \beta^{d}-X_{i t}^{s} \beta^{s}}{\sigma}\right)$

where $X_{i t}^{d}$ and $X_{i t}^{s}$ denote the variables that determine a firm's loan demand and the maximum amount of credit available to a firm, respectively. The error terms are assumed to be distributed normally, $\sigma^{2}=\operatorname{var}\left(u_{i t}^{d}-u_{i t}^{s}\right)$, and $\Phi($.$) is a standard normal$ distribution function. Since $E\left(\operatorname{loan}_{i t}^{d}\right)=X_{i t}^{d} \beta^{d} \quad$ and $\quad E\left(\operatorname{loan}_{i t}^{s}\right)=X_{i t}^{s} \beta^{s}$, $\operatorname{Pr}\left(\operatorname{loan}_{i t}^{d}>\operatorname{loan}_{i t}^{s}\right)>0.5$, if and only if $E\left(\operatorname{loan}_{i t}^{d}\right)>E\left(\operatorname{loan}_{i t}^{s}\right)$.

We extend our baseline model to study whether stronger bank-firm lending relationships augment credit availability as has been shown for example in Petersen and Rajan (1994). This implies adding bank-firm lending relationship variables to the Bank Loan supply equation (2). We include three indicators capturing the strength of a bankfirm relationship. In particular, we add the length of the relationship - measured as the 
number of years of the relationship between the firm and its main bank (we assume the main bank is either the only bank working with the firm or the bank with the longest relationship); a dummy variable showing whether the firm has a single (0) or multiple (1) bank relationships; and an interaction term of the lagged collateral variable (tangible fixed assets/total assets) times the length of the relationship trying to capture the impact of the length of the bank-firm relationship on the value of asset tangibility as collateral.

Testing Hypotheses 1 and 2 requires adding variables regarding different types of securitization to the loan supply equation. In particular, we include for each firm the main bank's issuance of ABS in a given year as a ratio of this bank's total loans at the beginning of that period (to test $\mathrm{H} 1$ ), the main bank issuance of covered bonds in a given year as a ratio of this bank's total loans at the beginning of that period (to test $\mathrm{H} 2$ ), the main bank size (as a proxy for the presence of that bank in debt and capital markets) and the main bank cost-to-income ratio (as a proxy for the efficiency of the bank that may also influence its ability to lend at a lower cost). In order to capture whether the relationship between ABS and covered bonds issuance and loan supply varied during the crisis years, we also include an interaction term between each one of the securitization issuance variables and a time dummy taking the value 1 for 2007 and 2008 and zero otherwise. An additional specification also considers a dummy which takes the value 1 for 2008 (when the crisis was more developed) and zero otherwise.

The definition and sources for our main variables are shown in Table 1; their descriptive statistics are in Table 2 . We observe that the average duration of the bankfirm relationship is 6.6 years. Additionally, $51 \%$ of the firms work with a single bank. As for the issuance of securities by the main bank, $14 \%$ of the loans over the period are securitized as ABS while $17 \%$ are securitized as covered bonds in our sample. 


\subsection{Spain as an empirical laboratory}

Spain offers a particularly advantageous environment in which to analyze our hypotheses. Spain has a banking-oriented financial system with a large fraction of its economic activity driven by SMEs which are highly dependent on bank credit and the most likely to be credit rationed. In 2008 SMEs represent $99.6 \%$ of the total number of firms and $53 \%$ of total employment in Spain. Spain is also a relatively attractive environment to study relationship lending because Spanish banks may focus more on relationship lending than in some other countries, particularly the U.S. For example, in the U.S. lenders historically had more transactions-based lending technologies such as small business credit scoring that can also be used in lending to opaque firms.

Another important feature that makes the Spanish case a particularly interesting one is the role of the lending cycle and both types of securitization before and during the financial crisis of 2007-2008. Spain has featured in a particularly prominent fashion in the current crisis attracting a big deal of international attention. Securitization activity grew spectacularly in this country in parallel with large increases in bank credit to the private sector. Indeed Spain has been largely labeled as a country where securitization activity grew from being almost insignificant in the late 1990's to finance a large portion of bank lending to the private sector in the years running up to the crisis. As shown in Figure 1, lending to firms in Spain varies significantly over the business cycle. In particular, the yearly lending growth rates at the beginning of our sample period in 1996 were $4.9 \%$. Lending to firms increased significantly in the years prior to the crisis reaching $30.1 \%$ in November 2006 and falling sharply afterwards to 6.8\% in December 2008.

On the back of an exceptional growth in bank credit the country also recorded a large rise in private sector debt. As in many episodes of banking problems across the 
world, the spectacular upward swing in the Spanish credit cycle was buttressed by particularly loose lending practices and large increases in housing prices (see Tornell and Westermann, 2002, and Reinhart and Rogoff, 2009). Hence the recent Spanish episode of financial instability shares many common features with a large number of prior banking crises (i.e. large increases in loan growth coupled with housing price bubbles). These features also emerged together with new factors such as financial innovation in general and most significantly in securitization markets.

Little has been said or explored on a possible role for securitization in triggering lending in countries that experienced a lending and housing bubble in the years before the crisis. On the latter, housing prices in the years prior to the crisis have been particularly noticeable in some European countries, the UK, Ireland and Spain - where housing prices have increased by more than $180 \%$ only between 1997 and 2007 - the largest growth among major industrialized countries.

The evolution of securitization in recent years offers some relevant information on the magnitude of ABS and covered bonds in Spain. According to the Securitization Industry and Financial Market Association (SIFMA) Spain was the third largest country in Europe in terms of outstanding ABS securitization with $€ 163.8$ bln. Only the UK ( $€$ $530.3 \mathrm{bln})$ and Netherlands ( $€ 188.9$ bln) exhibit higher outstanding ABS values. As for covered bonds, the European Covered Bond Council (ECBC) reports that Spain was the second largest market of covered bonds in Europe with an outstanding amount of Eur 352 bln, after Germany (Eur 719.4 bln). Spain therefore is an interesting setting to study to what extent those banks more active in $\mathrm{ABS}$ and covered bond issuance have altered their lending to firms thereby augmenting or mitigating credit rationing. Furthermore, we investigate the effects of both types of securitization during normal periods and during financial crisis. 
Using Dealogic and AIAF data Figure 2 shows the stock of covered bonds and $\mathrm{ABS}^{9}$ issued by Spanish commercial and savings banks from 1999 to 2008 . Covered bond issuance by commercial banks increased from $€ 0.5$ bln to $€ 112$ bln in that period while in the case of savings banks the stock of covered bonds grew from $€ 0.7$ bln to $€$ 135 bln. As for ABS, the stock at commercial banks was $€ 0.5$ in 1999 and it continuously increased to $€ 126$ bln in 2008 while the change at commercial banks during the same period was from $€ 0.4$ to $€ 134 \mathrm{bln}$.

\section{Results}

\subsection{Baseline model}

The estimated parameters of the baseline disequilibrium model (equations (1)(3)) are reported in column I of Table 3. The top panel displays the result for the "demand for bank loans". All the variables in the demand equation have the expected signs. As shown by the demand equation parameters, a $€ 1$ increase in sales augments the desired demand of bank loans by $€ 0.35$ while a $€ 1$ increase in cash flow reduces loan demand by $€ 0.99$. Additionally, a $€ 1$ increase in the cost of funds (loan interest spread) is found to reduce the desired demand of bank loans by $€ 1.16$.

The middle panel of Table 3 displays the results for the "supply of bank loans". As for the credit availability function, a $€ 1$ increase in collateral (measured by tangible fixed assets) increases the availability of loans by $€ 1.33$. As for the non-monetary variables, they enter the regressions multiplied by 100 to make the coefficient more tractable. The interpretation of these coefficients would be the expected impact on loans over total assets ${ }^{10}$. The age of the firm has a positive and significant impact on the

\footnotetext{
${ }^{9}$ ABS encompasses mortgage backed securities and some other forms of asset backed securities like consumer finance. In Spain, more than $90 \%$ of ABS are mortgage backed securities.

${ }^{10}$ Average loan/total assets is 0.16 in our sample and the standard deviation is 0.09 .
} 
supply of loans. The coefficient is 0.32 implying that a one standard deviation change (6.3) increases the loan over total assets of the firm by $0.02(0.32 / 100 * 6.3)$. Similarly one standard deviation increase in bank market power (Lerner index) has a negative impact on loans over total assets of -0.0013 (i.e., $-0.75 / 100 * 0.17$ ). The ratio "current assets/current liabilities" is not significant. The $\log (\mathrm{GDP})$ has a positive and significant impact in both the loan demand and loan supply equations. The estimation of the baseline model also reveals that $30.3 \%$ of the firms were constrained within our sample (row "percentage of borrowing constrained firms").

Columns II and III of Table 3 investigate an extended supply including relationship lending variables. The third panel of Table 3 displays the results of whether the strength of the bank-firm relationship influences credit supply and consequently credit rationing. Column II introduces two dimensions of relationship lending - the length (number of years) of the relationship with the main bank and the dummy showing the single vs. multiple relationship status - to the baseline model. Column II of Table 3 reveals that firms with a longer relationship with the main bank obtain a larger loan supply from their banks. In particular a one standard deviation increase in the length of the relationship makes the loans over total asset 0.005 larger $(0.148 / 100 * 3.44)$. Additionally, it is shown that those firms having multiple bank relationships are more likely to obtain bank loans from all banks (an increase in the loan to assets ratio of 0.37 percentage points compared to those banks having single banks relationships).

Column III in Table 3 investigates whether observed collateral values mitigate or strengthen the effects of the length of the relationship on loan supply. We add an interaction term between the asset tangibility variable and the length of the relationship variable. Both the length variable and the interaction terms are significant and positive 
at the $1 \%$ level which suggests that both collateral value and the length of the relationship are positive drivers of loan supply.

Taking the estimates of column III in Table 3 as a reference, Figure 3 depicts the estimated evolution of firm financing constraints within our sample, along with the average length of the relationships and the average percentage of firms having multiple vs. single relationships with banks. All the variables are adjusted to their mean in each year. Figure 3 shows that the percentage of constrained firms increased from $30.83 \%$ in 2006 to $36.80 \%$ in 2008 . During the same time period, the average length of lending relationships within our sample decreased from 7.23 to 6.71 years. As for the percentage of firms having relationships with multiple banks it decreased from $58.83 \%$ in 1993 to $41.27 \%$ in 2005 and remained stable around 40\% from 2006 to 2008.

\subsection{The role of different types of securitization: test of $\mathrm{H} 1$ and $\mathrm{H} 2$.}

Table 4 explores the role of banks' activities for the two types of securitization both for normal and crisis periods. In particular Table 4 investigates $\mathrm{H} 1$ and $\mathrm{H} 2$ regarding the impact of banks' activities in ABS and covered bonds on financing constraints. In this table, we extend the loan supply equation not only by incorporating the characteristics of the lending relationship with the main bank but also to include the securitization activity of the firm's main bank as well as other control variables of the characteristics of the firm's main bank such as its size and efficiency. Column I in table 4 shows that both the issuance of ABS and covered bonds (as a percent of total loans) at the beginning of the period has a positive impact on current lending to firms, consistent with the first part of $\mathrm{H} 1$ and $\mathrm{H} 2$. The coefficients represent how an increase in the proportion of $\mathrm{ABS}$ or covered bonds over total loans impact on the loan over total assets of the firm. The economic impact of a one standard deviation increase in the covered 
bonds issuance is significantly higher than the impact of ABS $(2.9(0.7382 * 0.04)$ and 0.8 percentage points $(0.1433 * 0.06)$, respectively). ${ }^{11}$ This result suggest that covered bonds, which theoretically are meant to be only liquidity generation devices, have a higher impact on lending to firms than ABS, which theoretically are meant to be both liquidity and risk transferring devices. Additionally, we find that the size of the main bank does not seem to have an impact on loan supply to firms while efficiency does have a positive impact (lower cost-to-income ratio) on loan supply, suggesting that reducing operating costs affects loan supply positively. In unreported specifications, we further find that the impact of both types of securitization on loan supply increases in the length of the relationship and when firms have multiple relationships. ${ }^{12}$

Taking the results of column 1 in Table 3 as a reference, Figure 4 displays the percentage of constrained firms (the black solid line). Figure 4 also shows the percentage of firms whose main banks issues ABS and covered bonds. While both ABS and covered bond issuance increase in the years before the crisis - in parallel to a decrease in firm financing constraints, the percentage of firms whose main bank was issuing ABS increased from $65.27 \%$ to $67.12 \%$ from 2006 to 2008 while the percentage of firms whose main bank was issuing covered bonds decreased from $68.32 \%$ to $57.47 \%$ in the same period.

In order to investigate whether $\mathrm{ABS}$ and covered bond issuance had a differential effect on loan supply during the crisis (the second part of $\mathrm{H} 1$ and H2), we interact the issuance variables with a time dummy taking the value 0 up to 2006 and 1 for 2007 and 2008. The results suggest that the issuance of ABS had a negative impact

\footnotetext{
${ }^{11}$ Results are robust to the exclusion of the "tangible fixed assets/total assets $\mathrm{x}$ length" as relationship lending variable.

${ }^{12}$ The coefficient on the interaction term for (i) "main bank issuance of ABS x length" equals $0.0523 * * *$, (ii) "main bank issuance of covered bonds x length" equals $0.1135^{* * *}$, (iii) "main bank issuance of ABS $\mathrm{x}$ single vs. multiple bank relationships" equals $0.0208^{* *}$ and (iv) "main bank issuance of covered bonds $\mathrm{x}$ single vs. multiple bank relationships" equals $0.1376^{* * * *}$.
} 
on loan supply during the crisis (the total impact during the crisis $(-0.2374)$ is the sum of the two coefficients +0.1352 and -0.3726 ) while covered bonds have a slightly higher positive effect during the crisis (the total impact during the crisis $(0.7259)$ is the sum of the two coefficients 0.7128 and 0.0131 ). This result suggests that while ABS may impact positively loan supply, this effect may turn negative during the downside of the lending cycle. These results hold when we restrict our crisis dummy to include 2008 only (see Model III of Table 4) ${ }^{13}$. Our results are therefore consistent with H1 and H2.

We also address the question of how these results are affected by potential sample selection. Since the dependent variable is the ratio of bank loans to assets of the firm, the distribution of this variable might shift if, for example, the years 2007 and 2008 implied that highly leveraged firms went bankrupt and, consequently, part of the drop of the demand that we observe could be due to the exit of those firms from the sample. However, our (unreported) results continue to hold if we run the model for a balanced sample of firms that stay in the sample over our entire sample period. The results are also robust when we run a regression estimating only the effect of ABS in the crisis period and a separate regression with only the effect of covered bonds in the crisis period.

\subsection{Robustness checks}

The different specifications of the disequilibrium model presented in Tables 3 and 4 exhibit stable parameter estimates for our main variables of interest. Importantly, as shown for all the specifications, the coincidence in the classification of firms between the baseline model and the rest of specification is around $90 \%$, which reinforces the robustness of the model to specification changes.

\footnotetext{
${ }^{13}$ For expositional simplicity we only use the dummy that compares the $1993-2006$ vs. $2007-2008$ in the rest of the tables.
} 
We further estimate four additional specifications to check the robustness of the results to firm size and bank ownership, interaction between securitization and bank characteristics, exposure of bank to real estate, and ABS issuance excluding loan sales, respectively. We report them in Tables 5 to 8 .

As for firm size, we extend our model by including a dummy which takes the value zero if the firm is large and one if the firm is an SME. (We consider that the firm is an SME if the number of employees is lower than 500.) As for bank ownership, the idea is to check whether there are differences in loan supply to firms between commercial and savings banks. Savings banks in Spain are stakeholder-based firms and do not quote in stock markets as commercial banks do. Additionally, savings banks have been more specialized in traditional lending activities than commercial banks and are frequently tied to a specific territory. Hence savings banks are more likely to get involved in relationship lending. Due to their specialization, savings banks are also, in principle, more likely to securitize loans given that their loan growth has been higher than the loan growth of commercial banks in the years before the crisis. Even if both commercial banks and savings banks are subjected to the same supervision and regulation in Spain, the abovementioned differences in ownership and specialization may have resulted in different lending practices.

We add these variables to the two first specifications discussed in Table 4 . The results of these extended models are shown in Table 5, columns I and II. The results for these additional variables are shown in the panel "Extended supply (II)". As for bank ownership, we find that loan supply seem to be significantly higher at savings banks since the dummy exhibits a positive and significant sign. The findings confirm that 
SMEs are more likely to be credit rationed since the coefficient of the dummy variable for firm size is negative and significant. ${ }^{14}$

We also study how the effects found for securitization depend upon specific bank characteristics. In particular we investigate whether these effects are significantly different at firms whose main bank exhibits a high vs. low liquidity and for firms whose main bank is a commercial vs. a savings bank. In order to undertake these tests, we interact the main bank securitization variables with these dummies ${ }^{15}$. As for the liquidity dummy, the variable takes the value 0 for those firms operating with a bank whose liquidity ratio (liquid assets/total assets) is below the median of the sample and 1 for those firms operating with a bank whose liquidity ratio is over the median. The results are shown in Table 6, panel "Extended supply (II)". While the liquidity of the banks does not seem to affect the impact of covered bond securitization on loan supply, it has a positive and significant effect in the case of ABS. This result suggests that positive effect of securitization on loan supply is conditioned to the liquidity holdings of the lender while the positive effect of covered bond securitization on loan supply seems to be unconditional on the liquidity level of the main bank. As for the interaction of securitization and bank ownership, no differences are found for ABS securitization while covered bond securitization seems to have a more significant and positive effect on bank loan supply at savings banks compared to commercial banks.

We test if banks with different exposure to the construction and real estate sector have a systematically different behaviour in what the relationship between lending patterns and securitization is concerned. As noted by Jiménez et al. (2010) Spain

\footnotetext{
${ }^{14}$ The impact of securitization by the main bank on loan supply seems somewhat less pronounced for SMEs. In unreported specifications we find that the coefficient on the interaction term of "main bank issuance of $\mathrm{ABS} x$ type of firm" equals $-0.0118^{* *}$ and "main bank issuance of covered bonds $\mathrm{x}$ type of firm"equals $-0.0496 * * *$.

${ }^{15}$ We also tested the interaction between the dummy showing single vs. multiple bank relationships and securitization but no significant differences were found.
} 
experienced a housing price bubble in the years before the financial crisis and this could have induced banks with higher exposure to the real estate and construction sector to securitize loans to a larger extent. Jiménez et al (2010) show that banks with more real estate loans as a fraction of their total loan portfolio lend to smaller firms that have more tangible assets and rely on longer term financing so that loans of real-estate dependent banks are more likely to be collateralized and have longer maturity. We also consider the exposure to the real estate and construction sector by looking at the share of loans that is given out to the real estate sector (residential, commercial, and construction). Since we rely on publicly available data from annual reports and prudential information reports published yearly by the banks we could only observe this exposure since 2000 . Our tests consists of re-running our baseline model of Table 4 for two groups of firms: i) those working with banks below the median value of the exposure to real estate sector (low real estate exposure banks) at the beginning of the year; ii) and those working with banks over the median value of the exposure to real estate sector (high real estate exposure banks) at the beginning of the year. The results are shown in Table 7, including in the last column a variance-covariance test for differences between both groups. Although the coefficients of low and high real estate exposure banks achieve the same signs and significance there are some statistical differences in the magnitude of the coefficients that are worth noting. In particular, the banks with a lower exposure to real estate assets show a significantly higher positive impact of the length of the relationship and single vs. multiple relationships on loan supply. Besides, the issuance of ABS and covered bonds have a significantly larger positive impact on loan supply for these low exposure banks and the positive (negative) effects of covered bonds (ABS) during crisis years is shown to be also larger (smaller) for banks with a lower exposure to real estate sector. Interestingly, the percentage of constrained firms for the sub- 
sample of firms working with banks having a low real estate exposure is lower $(28.63 \%)$ than in the sub-sample of firms having relationships with banks showing a larger exposure to real estate assets $(33.18 \%)$.

Finally, Table 8 reports the results where we exclude loan sales from the ABS. The motivation is that loan sales might be seen as an ex-ante risk signal by the issuing bank. The fraction of loan sales, however, is only about $12 \%$. The results in Table 8 are very similar to those of Table 4 where we included all ABS. This shows that our finding that $\mathrm{ABS}$ issuers reduce their lending during the financial crisis stems from an ex-post effect of previously higher risk adoption.

\section{Conclusions}

The pros and cons of securitization are hotly debated. In this paper we investigate the role of securitization for credit rationing through its influence on lending relationships during normal and crisis periods. Employing a disequilibrium model, we first establish that firms with a more intense lending relationship as measured through its duration and the lower number of banks they are dealing with, enjoy a greater credit supply and lower degree of credit rationing.

Securitization activity of the firm's main bank helps in reducing credit constraints. Indeed, firms having relationships with banks being more involved in securitization activities enjoy lower credit constraints in normal periods; however, they also face increased credit rationing during crisis periods. This shows that securitization generates supply effects which differ in normal and crisis periods. Finally, we show that there is heterogeneity within securitization. We do this by investigating the impact of different types of securitization - asset and mortgage backed securities (ABS) and covered bonds - on credit rationing. While both types of securitization reduce credit 
rationing in normal periods, the main bank issuance of $\mathrm{ABS}$ aggravates credit rationing in crisis periods. We hypothesized that better quality of underlying assets in covered bonds or fears of the market towards securitization (one of the culprits of the financial crisis) as the main sources of the differences between covered bonds and ABS in our findings. 


\section{References}

Acharya, V., P. Schnabl, and G. Suarez (2011), Securitization without Risk Transfer, forthcoming in Journal of Financial Economics.

Atanasova C.V., and N. Wilson (2004), Disequilibrium in the UK corporate loan market, Journal of Banking and Finance, 28: 595-614.

Burkart, M., T. Ellingsen and M. Giannetti (2011), What you sell is what you lend? Explaining Trade Credit Contracts, Review of Financial Studies, 24, 1261-1298.

Carbó, S., Marqués, D. and F. Rodríguez (2011), Securitization, risk transferring and financial instability: the case of Spain, Journal of International Money and Finance, forthcoming.

Carbó, S., F. Rodríguez, and R. Rosen (2012), Are Covered Bonds a Substitute for Mortgage Backed Securities?, FRB of Chicago Working Paper, 2011-14.

Carbó, S., F. Rodríguez, and G. F. Udell (2009), Bank Market Power and SME Financing Constraints, Review of Finance, 13: 309-340.

Degryse, H., V. Ioannidou and E. von Schedvin (2012), On the Non-Exclusivity of Loan Contracts: An Empirical Investigation, CEPR DP 8692.

Degryse, H., M. Kim and S. Ongena (2009), The Microeconometrics of Banking: Applications, Methods and Results, Oxford University Press.

Degryse, H., N. Masschelein and J. Mitchell (2011), Staying, Dropping or Switching: The impact of Bank Mergers on Small Firms, Review of Financial Studies, 24, 1102-1140.

Dell'Ariccia, G., D. Igan and L. Laeven (2012), Credit Booms and Lending Standards: Evidence from the Subprime Mortgage Market, Journal of Money, Credit and Banking, 44, 367-384.

Drucker, S. and M. Puri (2009), On Loan Sales, Loan Contracting, and Lending Relationships, Review of Financial Studies, 22, 2835-2872.

Duffie D. (2007), Innovations in Credit Risk Transfer: Implications for Financial Stability, Stanford University Working Paper.

Gersovitz, M. (1980), Classification Probabilities for the Disequilibrium Model, Journal of Econometrics, 41: 239-246.

Hirtle, B. (2007), Credit Derivatives and Bank Credit Supply, Federal Reserve Bank of New York Staff Report no. 276.

Irani, R. (2012), Bank Health and Corporate Liquidity Provision, mimeo, NYU Stern. 
Jiménez, G., A.R. Mian, J.L. Peydró, and J. Saurina (2010), Local Versus Aggregate Lending Channels: The Effects of Securitization on Corporate Credit Supply in Spain, NBER Discussion Paper 16595.

Kara, A., D. Marqués-Ibáñez, and S. Ongena (2011). Securitization and Lending Standards - Evidence from the Wholesale Loan Market, European Central Bank Working Paper 1362.

Keys, B.J., A. Seru, and V. Vig. (2011), Lender Screening and Role of Securitization: Evidence from Prime and Subprime Mortgage Markets, Review of Financial Studies, forthcoming.

Keys, B., T. Mukherjee, A. Seru and V. Vig (2010), Did Securitization Lead to Lax Screening: Evidence from Subprime Loans 2001-2006, Quarterly Journal of Economics, 125(1), 307-362.

Kirschenmann, K. (2010), Credit rationing in small business bank relationships, mimeo, available at www.ssrn.com.

Loutskina, E. and P. Strahan (2009), Securitization and the declining impact of bank financial condition on loan supply: Evidence from mortgage originations. Journal of Finance, 64(2), 861-922.

Maddala, G.S. and F.D. Nelson (1974), Maximum likelihood methods for models of markets in disequilibrium, Econometrica 42: 1013-1030.

Maddala, G.S. (1980), Disequilibrium, self-selection and switching models, Social Science Working Paper 303, California Institute of Technology, February.

Maddaloni, A., and J.L. Peydró (2011), Bank Risk-taking, Securitization, Supervision, and Low Interest Rates: Evidence from Euro-area and US Lending Standards, Review of Financial Studies, 24, 2121-2165.

Mian, A.R. and A. Sufi (2009), The Consequences of Mortgage Credit Expansion: Evidence from the U.S. Mortgage Default Crisis., Quarterly Journal of Economics, 124, 1449-1496.

Nini, G. (2008), How Non-Banks Increased the Supply of Bank Loans: Evidence from Institutional Term Loans, mimeo, Wharton School.

Ogawa, K. and K. Suzuki (2000), Demand for bank loans and investment under borrowing constraints: a panel study of Japanese firm data, Journal of the Japanese and International Economies 14: 1-21.

Panetta F. and A. Pozzolo (2010), Why Do Banks Transfer Credit Risk? Bank-Level Evidence From Over One Hundred Countries, mimeo.

Perez, S.J. (1998), Testing for credit rationing: an application of disequilibrium econometrics, Journal of Macroeconomics 20: 721-739. 
Petersen, M. and R. Rajan (1994), The Benefits of Lending Relationships: Evidence from Small Business Data, Journal of Finance, 1, pp.3-37.

Puri, M., J. Rocholl and S. Steffen (2011), Global Retail Lending in the Aftermath of the US Financial Crisis: Distinguishing between Demand and Supply Effects, Journal of Financial Economics, 100, 556-578.

Reinhart, C and K. S. Rogoff (2009), This Time It's Different: Eight Centuries of Financial Folly, Princeton: Princeton University Press.

Sealey, C.W. (1979), Credit rationing in the commercial loan market: estimates of a structural model under conditions of disequilibrium, Journal of Finance 34: 689702.

Shivdasani, A. and Y. Wang (2011), Did Structured Credit Fuel the LBO Boom?, Journal of Finance 66: 1291-1328.

Steijvers, T. (2008), Existence of credit rationing for SME's in the Belgian corporate bank loan market, mimeo.

Stiglitz, J. and A. Weiss (1981), Credit rationing in markets with imperfect information, American Economic Review 71: 393-410.

Tornell, A. and F. Westermann (2002), Boom-bust cycles in middle income countries: Facts and explanation, National Bureau of Economic Research Working Paper Series 9219.

Wagner, W and I.W. Marsh (2006), Credit Risk Transfer and Financial Sector Performance. Journal of Financial Stability 2, 173-193. 
TABLE 1. DEFINITION OF THE MAIN VARIABLES

\begin{tabular}{|c|c|c|}
\hline & Definition & Source \\
\hline Sales & Total sales during the year (thousand of $€$ ) & SABI \\
\hline Cash flow & $\begin{array}{l}\text { Net income plus depreciation plus changes in deferred } \\
\text { taxes (thousand of } € \text { ) }\end{array}$ & SABI \\
\hline Loan interest spread & $\begin{array}{l}\text { Difference between loan interest rates and interbank } \\
\text { rates. The loan interest rate is computed as a ratio of } \\
\text { loan expenses and bank loans outstanding. We } \\
\text { implicitly assume that the year-end loan balance is } \\
\text { roughly equal to the weighted average balance during } \\
\text { the year. }\end{array}$ & $\begin{array}{l}\text { SABI and } \\
\text { ECB }\end{array}$ \\
\hline$G D P$ & $\begin{array}{l}\text { Gross domestic product in the region where the firm } \\
\text { operate }\end{array}$ & $\begin{array}{c}\text { Spanish } \\
\text { Statistical } \\
\text { Office (INE) } \\
\end{array}$ \\
\hline Tangible assets & $\begin{array}{l}\text { Fixed assets on firm's balance sheet (thousand of } € \text { ). } \\
\text { This is considered as proxy of collateral. }\end{array}$ & SABI \\
\hline Age of the firm & Number of years since the firm was created. & SABI \\
\hline Lerner index & $\begin{array}{l}\text { Ratio "(price of total assets - marginal costs of total } \\
\text { assets)/price". The price of total assets is directly } \\
\text { computed from the bank-level auxiliary data as the } \\
\text { average ratio of "bank revenue/total assets" for the } \\
\text { banks operating in a given region using the distribution } \\
\text { of branches of banks in the different regions as the } \\
\text { weighting factor. Marginal costs are estimated from a } \\
\text { translog cost function with a single output (total assets) } \\
\text { and three inputs (deposits, labor and physical capital) } \\
\text { using two stage least squares and bank fixed effects. }\end{array}$ & $\begin{array}{l}\text { Spanish } \\
\text { Commercial } \\
\text { Banks } \\
\text { Association } \\
\text { (AEB) and } \\
\text { the Spanish } \\
\text { Savings Bank } \\
\text { Confederation } \\
\text { (CECA). }\end{array}$ \\
\hline Default risk & $\begin{array}{l}\text { This risk variable is defined as the ratio of operating } \\
\text { profits to interest paid. A proxy for operating risk } \\
\text { showing how many times interest paid are covered by } \\
\text { operating profits. }\end{array}$ & SABI \\
\hline Length (n. years relationship) & $\begin{array}{l}\text { Number of years of bank-firm relationship with the } \\
\text { main bank }\end{array}$ & SABI \\
\hline Single vs. multiple bank relationships & $\begin{array}{l}\text { A dummy that takes the value } 0 \text { if the relationship is } \\
\text { just with one bank and } 1 \text { if it is with more than } 1 \text { bank. }\end{array}$ & SABI \\
\hline Main bank issue ABS (\% loans) & $\begin{array}{l}\text { Main bank's issuance of ABS in a given year as a ratio } \\
\text { of this bank's total loans at the beginning of the period. }\end{array}$ & Dealogic \\
\hline $\begin{array}{l}\text { Main bank issue covered bonds (\% } \\
\text { loans) }\end{array}$ & $\begin{array}{l}\text { Main bank issuance of covered bonds in a given year as } \\
\text { a ratio of total loans at the beginning of the period. }\end{array}$ & Dealogic \\
\hline Main bank size /(log total assets) & $\begin{array}{l}\text { Size (total assets) of the bank that holds the main } \\
\text { relationship with the firm. }\end{array}$ & $\begin{array}{l}\text { Spanish } \\
\text { Commercial } \\
\text { Banks } \\
\text { Association } \\
\text { (AEB) and } \\
\text { the Spanish } \\
\text { Savings Bank } \\
\text { Confederation } \\
\text { (CECA). } \\
\end{array}$ \\
\hline Main bank cost-to-income-ratio & $\begin{array}{l}\text { Efficiency (cost/income ratio) of the bank that holds the } \\
\text { main relationship with the firm. }\end{array}$ & $\begin{array}{l}\text { Spanish } \\
\text { Commercial } \\
\text { Banks } \\
\text { Association } \\
\text { (AEB) and } \\
\text { the Spanish } \\
\text { Savings Bank } \\
\text { Confederation } \\
\text { (CECA). } \\
\end{array}$ \\
\hline
\end{tabular}


TABLE 2. DESCRIPTIVE STATISTICS (1993-2008)

\begin{tabular}{|c|c|c|c|c|c|c|c|}
\hline & 1993-1996 & 1997-2000 & 2001-2004 & $2005-2006$ & 2007-2008 & 1993-2008 & $\begin{array}{l}\text { Std. } \\
\text { dev. }\end{array}$ \\
\hline Sales & 13953.2 & 16632.5 & 17267.3 & 19718.4 & 16121.0 & 16287.3 & 5230.1 \\
\hline Cash flow & 1326.3 & 1532.2 & 1639.6 & 1824.1 & 1653.4 & 1590.5 & 698.3 \\
\hline Loan interest spread & 0.0168 & 0.0159 & 0.0141 & 0.0127 & 0.0125 & 0.0131 & 0.0089 \\
\hline$G D P$ & 45258 & 49223 & 53524 & 56832 & 57412 & 52228 & 14431.6 \\
\hline Tangible assets & 1395.5 & 1458.4 & 1606.1 & 1892.5 & 1694.2 & 1539.6 & 394.7 \\
\hline Age of the firm & 10.12 & 10.26 & 10.54 & 11.31 & 10.88 & 10.53 & 6.3 \\
\hline Lerner index & 0.2102 & 0.2304 & 0.2403 & 0.2419 & 0.2412 & 0.2488 & 0.1721 \\
\hline Default risk & 3.14 & 3.84 & 3.04 & 5.42 & 5.23 & 4.12 & 2.1 \\
\hline Length (n. years relationship) & 6.25 & 6.43 & 6.59 & 6.87 & 6.71 & 6.60 & 3.44 \\
\hline $\begin{array}{l}\text { Single vs. multiple bank } \\
\text { relationships }\end{array}$ & 0.53 & 0.51 & 0.50 & 0.48 & 0.44 & 0.49 & 0.48 \\
\hline Main bank issue ABS (\% loans) & 0.0 & 0.07 & 0.13 & 0.15 & 0.13 & 0.14 & 0.06 \\
\hline $\begin{array}{l}\text { Main bank issue covered bonds } \\
(\% \text { loans) }\end{array}$ & 0.0 & 0.05 & 0.14 & 0.17 & 0.21 & 0.17 & 0.04 \\
\hline Main bank size /(log total assets) & 8.14 & 8.46 & 8.88 & 9.03 & 8.89 & 8.63 & 1.59 \\
\hline Main bank cost-to-income-ratio & 0.70 & 0.68 & 0.64 & 0.60 & 0.68 & 0.66 & 0,28 \\
\hline
\end{tabular}




\begin{tabular}{|c|c|c|c|c|c|c|}
\hline \multicolumn{7}{|c|}{$\begin{array}{l}\text { TABLE 3. ESTIMATED PARAMETERS OF THE DISEQUILIBRIUM MODEL. ALTERNATIVI } \\
\text { BASELINE MODEL AND RELATIONSHIP LENDING (1993-2008) } \\
\text { Switching regression model estimated by full information maximum likelihood (FIML) with bank and firm fixed effects } \\
\text { p-values in parenthesis } \\
\text { Standard errors are clustered at the regional level }\end{array}$} \\
\hline \multirow[b]{2}{*}{ Demand for bank loans } & \multicolumn{2}{|c|}{ (I) } & \multicolumn{2}{|c|}{ (II) } & \multicolumn{2}{|c|}{ (III) } \\
\hline & Coefficient & Std. Error & Coefficient & Std. Error & Coefficient & Std. Error \\
\hline Sales/total assets(t-1) & $\begin{array}{c}0.3526^{* * * *} \\
(0.000)\end{array}$ & 0.01 & $\begin{array}{c}0.3728 * * * \\
(0.000)\end{array}$ & 0.01 & $\begin{array}{c}0.3243 * * * \\
(0.000)\end{array}$ & 0.01 \\
\hline Cash-flow/total assets(t-1) & $\begin{array}{c}-0.9861 * * * * \\
(0.000)\end{array}$ & 0.06 & $\begin{array}{c}-1.1106 * * * \\
(0.000)\end{array}$ & 0.06 & $\begin{array}{c}-0.8435 * * * \\
(0.000)\end{array}$ & 0.07 \\
\hline Loan interest spread & $\begin{array}{c}-1.1640 * * * \\
(0.000)\end{array}$ & 0.03 & $\begin{array}{c}-1.0563^{* * *} \\
(0.000)\end{array}$ & 0.03 & $\begin{array}{c}-1.0388^{* * *} * \\
(0.000)\end{array}$ & 0.03 \\
\hline $\log (G D P)$ & $\begin{array}{c}0.0147 * * \\
(0.042) \\
\end{array}$ & 0.01 & $\begin{array}{c}0.0128^{* * *} \\
(0.015) \\
\end{array}$ & 0.01 & $\begin{array}{c}0.0131^{* *} \\
(0.018) \\
\end{array}$ & 0.01 \\
\hline \multicolumn{7}{|l|}{ Supply of bank loans } \\
\hline Tangible fixed assets/total assets(t-1) & $\begin{array}{c}1.3285^{* * * *} \\
(0.000)\end{array}$ & 0.01 & $\begin{array}{c}1.1728 * * * \\
(0.000)\end{array}$ & 0.01 & - & - \\
\hline Age of the firm & $\begin{array}{c}0.3226^{* * * *} \\
(0.000)\end{array}$ & 0.01 & $\begin{array}{c}0.2989 * * * \\
(0.000)\end{array}$ & 0.01 & $\begin{array}{c}0.3125 * * * \\
(0.000)\end{array}$ & 0.01 \\
\hline Banks' market power (Lerner index) & $\begin{array}{c}-0.7523 * * \\
(0.023) \\
\end{array}$ & 0.01 & $\begin{array}{c}-0.7088^{* * * *} \\
(0.03)\end{array}$ & 0.01 & $\begin{array}{c}-0.7112 * * * * \\
(0.007)\end{array}$ & $0 . .01$ \\
\hline Loan interest spread & $\begin{array}{c}1.2860^{* * * *} \\
(0.000)\end{array}$ & 0.05 & $\begin{array}{c}1.1363^{* * * *} \\
(0.000)\end{array}$ & 0.04 & $\begin{array}{c}1.0780 \text { **** } \\
(0.000)\end{array}$ & 0.05 \\
\hline Default risk & $\begin{array}{l}0.0012 \\
(0.752)\end{array}$ & 0.02 & $\begin{array}{l}0.0010 \\
(0.805)\end{array}$ & 0.01 & $\begin{array}{l}0.0008 \\
(0.721)\end{array}$ & 0.01 \\
\hline $\log (G D P)$ & $\begin{array}{c}0.0662 * * * \\
(0.002)\end{array}$ & 0.01 & $\begin{array}{c}0.0764 * * \\
(0.013) \\
\end{array}$ & 0.01 & $\begin{array}{c}-0.0693^{* *} \\
(0.014)\end{array}$ & 0.01 \\
\hline \multicolumn{7}{|l|}{ Extended supply: relationship lending } \\
\hline Length (n. years relationship) & - & - & $\begin{array}{c}0.1480 * * * \\
(0.001)\end{array}$ & 0.01 & $\begin{array}{c}0.1374 * * * * \\
(0.001)\end{array}$ & 0.01 \\
\hline Single vs. multiple bank relationships & - & - & $\begin{array}{c}0.3742 * * * \\
(0.001)\end{array}$ & 0.01 & $\begin{array}{c}0.3963^{* * * *} \\
(0.001)\end{array}$ & 0.01 \\
\hline Tangible fixed assets/total assets(t-1)X Length & - & - & ( & - & $\begin{array}{c}1.2230 \text { **** } \\
(0.001)\end{array}$ & 0.01 \\
\hline Reciprocal of total assets in the loan demand equation & $\begin{array}{l}389664.1 * * * \\
(0.000)\end{array}$ & 1338.2 & $\begin{array}{l}397351.1^{* * * *} \\
(0.000)\end{array}$ & 1356.2 & $\begin{array}{l}384521.6^{* * * *} \\
(0.000)\end{array}$ & 1322.4 \\
\hline Reciprocal of total assets in the loan supply equation & $\begin{array}{c}294386.6^{* * * *} \\
(0.000) \\
\end{array}$ & 2577.3 & $\begin{array}{c}297825.4 * * * \\
(0.000)\end{array}$ & 2604.3 & $\begin{array}{c}284020.2^{* * *} \\
(0.000)\end{array}$ & 2523.6 \\
\hline S.D. of the disturbance in demand equation & $\begin{array}{c}1.3215^{* * * *} \\
(0.000)\end{array}$ & 0.01 & $\begin{array}{c}1.2843^{* * *} \\
(0.000)\end{array}$ & 0.01 & $\begin{array}{c}1.2082^{* * *} \\
(0.000)\end{array}$ & 0.01 \\
\hline S.D. of the disturbance in supply equation & $\begin{array}{c}0.3704 * * * \\
(0.000)\end{array}$ & 0.01 & $\begin{array}{c}0.3952 * * * \\
(0.000)\end{array}$ & 0.01 & $\begin{array}{c}0.4228^{* * * *} \\
(0.000)\end{array}$ & 0.01 \\
\hline Correlation coefficient between both disturbances & $\begin{array}{c}0.5325 * * * \\
(0.000)\end{array}$ & 0.04 & $\begin{array}{c}0.5581 * * * \\
(0.000)\end{array}$ & 0.04 & $\begin{array}{c}0.5731 * * * \\
(0.000)\end{array}$ & 0.04 \\
\hline Log likelihood & \multicolumn{2}{|c|}{169044} & \multicolumn{2}{|c|}{176320} & \multicolumn{2}{|c|}{172106.5} \\
\hline Percentage of borrowing constrained firms & \multicolumn{2}{|c|}{$30.3 \%$} & \multicolumn{2}{|c|}{$28.4 \%$} & \multicolumn{2}{|c|}{$28.2 \%$} \\
\hline $\begin{array}{l}\text { Coincidence in the classification of firms as constrained (relative } \\
\text { to specification (I)) }\end{array}$ & \multicolumn{2}{|c|}{-} & \multicolumn{2}{|c|}{$95.5 \%$} & \multicolumn{2}{|c|}{$95.4 \%$} \\
\hline Observations & \multirow{2}{*}{\multicolumn{2}{|c|}{$\frac{326,332}{56,752}$}} & \multirow{2}{*}{\multicolumn{2}{|c|}{$\frac{326,332}{56,752}$}} & \multicolumn{2}{|c|}{326,332} \\
\hline Number of firms & & & & & & \\
\hline
\end{tabular}




\section{TABLE 4. ESTIMATED PARAMETERS OF THE DISEQUILIBRIUM MODEL. ALTERNATIVE SPECIFICATIONS: RELATIONSHIP LENDING AND SECURITIZATION (1993-2008) \\ Switching regression model estimated by full information maximum likelihood (FIML) with bank and firm fixed effects}

p-values in parenthesis (Standard errors are clustered at the regional level)

\begin{tabular}{|c|c|c|c|c|c|c|}
\hline \multirow[b]{2}{*}{ Demand for bank loans } & \multicolumn{2}{|l|}{ (I) } & \multicolumn{2}{|c|}{ (II) } & \multicolumn{2}{|c|}{ (III) } \\
\hline & Coefficient & $\begin{array}{c}\text { Std. } \\
\text { Error }\end{array}$ & Coefficient & $\begin{array}{c}\text { Std. } \\
\text { Error }\end{array}$ & Coefficient & $\begin{array}{c}\text { Std. } \\
\text { Error }\end{array}$ \\
\hline Sales/total assets $(t-1)$ & $\begin{array}{c}0.3142 * * * \\
(0.000)\end{array}$ & 0.01 & $\begin{array}{c}0.3308^{* * * *} \\
(0.000)\end{array}$ & 0.01 & $\begin{array}{c}0.3006^{* * * * *} \\
(0.000)\end{array}$ & 0.01 \\
\hline Cash-flow/total assets(t-1) & $\begin{array}{c}-0.9614 * * * \\
(0.000) \\
\end{array}$ & 0.03 & $\begin{array}{c}-0.9182 * * * \\
(0.000)\end{array}$ & 0.05 & $\begin{array}{c}-0.9021 * * * \\
(0.000)\end{array}$ & 0.04 \\
\hline Loan interest spread & $\begin{array}{c}-1.1415^{* * *} * \\
(0.000)\end{array}$ & 0.04 & $\begin{array}{c}-1.1630 * * * \\
(0.000)\end{array}$ & 0.03 & $\begin{array}{c}-1.1162 * * * \\
(0.000)\end{array}$ & 0.03 \\
\hline $\log (G D P)$ & $\begin{array}{c}0.0140 * * \\
(0.041)\end{array}$ & 0.01 & $\begin{array}{c}0.0114 * * \\
(0.024)\end{array}$ & 0.01 & $\begin{array}{c}0.0112 * * \\
(0.029)\end{array}$ & 0.01 \\
\hline \multicolumn{7}{|l|}{ Supply of bank loans } \\
\hline Tangible fixed assets/total assets $(t-1)$ & $\begin{array}{c}1.4427 * * * \\
(0.000)\end{array}$ & 0.01 & $\begin{array}{c}1.3279 * * * \\
(0.000)\end{array}$ & 0.01 & $\begin{array}{c}1.3413^{* * *} * \\
(0.000)\end{array}$ & 0.01 \\
\hline Age of the firm & $\begin{array}{c}0.3230 * * * \\
(0.000)\end{array}$ & 0.01 & $\begin{array}{c}0.3606 * * * \\
(0.000)\end{array}$ & 0.01 & $\begin{array}{c}0.3526 * * \\
(0.000)\end{array}$ & 0.01 \\
\hline Banks' market power (Lerner index) & $\begin{array}{c}-0.7508^{* *} \\
(0.027)\end{array}$ & 0.04 & $\begin{array}{c}-0.7028^{* * *} * \\
(0.021)\end{array}$ & 0.01 & $\begin{array}{c}-0.7127 * * \\
(0.021)\end{array}$ & 0.01 \\
\hline Loan interest spread & $\begin{array}{c}1.0626^{* * * *} \\
(0.000)\end{array}$ & 0.04 & $\begin{array}{c}1.4750 * * * \\
(0.000)\end{array}$ & 0.04 & $\begin{array}{c}1.4073^{* * * *} \\
(0.000)\end{array}$ & 0.04 \\
\hline Default risk & $\begin{array}{l}0.0018 \\
(0.890) \\
\end{array}$ & 0.00 & $\begin{array}{l}0.0010 \\
(0.804) \\
\end{array}$ & 0.00 & $\begin{array}{l}0.0014 \\
(0.814) \\
\end{array}$ & 0.00 \\
\hline $\log (G D P)$ & $\begin{array}{c}0.0714 * * * \\
(0.001)\end{array}$ & 0.02 & $\begin{array}{c}0.0813 * * * \\
(0.001)\end{array}$ & 0.02 & $\begin{array}{c}0.0829 * * * \\
(0.001)\end{array}$ & 0.02 \\
\hline \multicolumn{7}{|l|}{ Extended supply $(I):$ relationship lending } \\
\hline Length (n. years relationship) & $\begin{array}{c}0.1249 * * * * \\
(0.001)\end{array}$ & 0.01 & $\begin{array}{c}0.1119 \text { **** } \\
(0.001)\end{array}$ & 0.01 & $\begin{array}{c}0.1183 \text { **** } \\
(0.001)\end{array}$ & 0.01 \\
\hline Single vs. multiple bank relationships & $\begin{array}{c}0.3511 \text { *** } \\
(0.001)\end{array}$ & 0.01 & $\begin{array}{c}0.3680 * * * \\
(0.001)\end{array}$ & 0.01 & $\begin{array}{c}0.3651 \text { *** } \\
(0.001)\end{array}$ & 0.01 \\
\hline Tangible fixed assets/total assets( $t-1) X$ Length & $\begin{array}{c}1.2338 * * * * \\
(0.001)\end{array}$ & 0.01 & $\begin{array}{c}1.2013 * * * * \\
(0.001)\end{array}$ & 0.01 & $\begin{array}{c}1.1264 * * * * \\
(0.001)\end{array}$ & 0.01 \\
\hline \multicolumn{7}{|l|}{ Extended supply (II): Main bank characteristics and securitization issues } \\
\hline Main bank issuance of $A B S$ (ABS issuance/total loans)t-1 & $\begin{array}{c}0.1433^{* *} \\
(0.001) \\
\end{array}$ & 0.01 & $\begin{array}{c}0.1358^{* * *} \\
(0.001)\end{array}$ & 0.01 & $\begin{array}{c}0.1127 \text { *** } \\
(0.001)\end{array}$ & 0.01 \\
\hline Main bank issuance of covered bonds (covered bonds issuance over total loans)t-1 & $\begin{array}{c}0.7382 * * * \\
(0.001)\end{array}$ & 0.01 & $\begin{array}{c}0.7128 * * * \\
(0.001) \\
\end{array}$ & 0.01 & $\begin{array}{c}0.6326^{* * * *} \\
(0.001)\end{array}$ & 0.01 \\
\hline Dummy (1993-2006 vs. 2007-2008) & - & - & $\begin{array}{c}-0.1144 * * \\
(0.014)\end{array}$ & 0.01 & $\begin{array}{c}-0.1914^{* *} \\
(0.018)\end{array}$ & 0.01 \\
\hline $\begin{array}{l}\text { Main bank issuance of ABS (ABS issuance/total loans)t-1 X Dummy (1993-2006 vs. } \\
\text { 2007-2008) }\end{array}$ & - & - & $\begin{array}{c}-0.3728^{* *} \\
(0.011) \\
\end{array}$ & 0.01 & - & - \\
\hline $\begin{array}{l}\text { Main bank issuance of covered bonds (covered bonds issuance over total loans)t-1 } \\
\text { X Dummy (1993-2006 vs. 2007-2008) }\end{array}$ & - & - & $\begin{array}{c}0.0123 * * \\
(0.032)\end{array}$ & 0.01 & - & - \\
\hline $\begin{array}{l}\text { Main bank issuance of ABS (ABS issuance/total loans)t-1 X Dummy (1993-2007 vs. } \\
\text { 2008) }\end{array}$ & - & - & - & - & $\begin{array}{c}-0.3426 * * \\
(0.010) \\
\end{array}$ & 0.01 \\
\hline $\begin{array}{l}\text { Main bank issuance of covered bonds (covered bonds issuance over total loans)t-1 } \\
\text { Dummy (1993-2007 vs.2008) }\end{array}$ & - & - & - & - & $\begin{array}{c}0.0118^{* *} \\
(0.021)\end{array}$ & 0.01 \\
\hline 2 & $\begin{array}{l}0.0145 \\
(0.127)\end{array}$ & 0.02 & $\begin{array}{l}0.0157 \\
(0.213)\end{array}$ & 0.02 & $\begin{array}{l}0.0153 \\
(0.215)\end{array}$ & 0.02 \\
\hline Main bank cost-to-income ratio & $\begin{array}{c}-0.1916^{* * *} \\
(0.020)\end{array}$ & 0.01 & $\begin{array}{c}-0.1817^{* *} \\
(0.029)\end{array}$ & 0.01 & $\begin{array}{c}-0.1734 * * \\
(0.030) \\
\end{array}$ & 0.01 \\
\hline Reciprocal of total assets in the loan demand equation & $\begin{array}{c}364229.1 * * * \\
(0.000)\end{array}$ & 1428.0 & $\begin{array}{c}382553.1 * * * \\
(0.000)\end{array}$ & 1329.5 & $\begin{array}{c}372218.1 * * * \\
(0.000)\end{array}$ & 1353.8 \\
\hline Reciprocal of total assets in the loan supply equation & $\begin{array}{c}260370.2^{* * * *} \\
(0.000)\end{array}$ & 2236.1 & $\begin{array}{c}272642.3^{* * * *} \\
(0.000)\end{array}$ & 2493.6 & $\begin{array}{c}278163.2^{* * * *} \\
(0.000)\end{array}$ & 2327.4 \\
\hline S.D. of the disturbance in demand equation & $\begin{array}{c}1.2653^{* * *} \\
(0.000)\end{array}$ & 0.01 & $\begin{array}{c}1.2582^{* * *} \\
(0.000)\end{array}$ & 0.01 & $\begin{array}{c}1.2542^{* * *} \\
(0.000)\end{array}$ & 0.01 \\
\hline S.D. of the disturbance in supply equation & $\begin{array}{c}0.3324 * * * \\
(0.000)\end{array}$ & 0.01 & $\begin{array}{c}0.3163 * * * \\
(0.000)\end{array}$ & 0.01 & $\begin{array}{c}0.3213^{* * * *} \\
(0.000)\end{array}$ & 0.01 \\
\hline Correlation coefficient between both disturbances & $\begin{array}{c}0.4463 * * * \\
(0.000) \\
\end{array}$ & 0.03 & $\begin{array}{c}0.5029 * * * \\
(0.000)\end{array}$ & 0.04 & $\begin{array}{c}0.5146 * * * \\
(0.000)\end{array}$ & 0.04 \\
\hline Log likelihood & \multicolumn{2}{|c|}{126920} & \multicolumn{2}{|c|}{152052} & \multicolumn{2}{|c|}{150118} \\
\hline Percentage of borrowing constrained firms & \multicolumn{2}{|c|}{$29.22 \%$} & \multicolumn{2}{|c|}{$30.38 \%$} & \multicolumn{2}{|c|}{$30.20 \%$} \\
\hline Coincidence in the classification of firms as constrained (relative to Table 3, (I)) & \multicolumn{2}{|c|}{$89.5 \%$} & \multicolumn{2}{|c|}{$91.1 \%$} & \multicolumn{2}{|c|}{$91.3 \%$} \\
\hline Observations & \multirow{2}{*}{\multicolumn{2}{|c|}{$\frac{326,332}{56,752}$}} & \multicolumn{2}{|c|}{326,332} & \multicolumn{2}{|c|}{326,332} \\
\hline Number of firms & & 56,752 & \multicolumn{2}{|c|}{56,752} & \multicolumn{2}{|c|}{56,752} \\
\hline
\end{tabular}




\section{TABLE 5. ESTIMATED PARAMETERS OF THE DISEQUILIBRIUM MODEL. ROBUSTNESS TESTS: BANK \\ OWNERSHIP AND FIRM SIZE (1993-2008)}

Switching regression model estimated by full information maximum likelihood (FIML) with bank and firm fixed effects

p-values in parenthesis Standard errors are clustered at the regional level

\begin{tabular}{|c|c|c|c|c|}
\hline \multirow[b]{2}{*}{ Demand for bank loans } & \multicolumn{2}{|c|}{ (I) } & \multicolumn{2}{|c|}{ (II) } \\
\hline & Coefficient & Std. Error & Coefficient & Std. Error \\
\hline Sales/total assets $(t-1)$ & $\begin{array}{c}0.2352 * * * \\
(0.000)\end{array}$ & 0.01 & $\begin{array}{c}0.3602 * * * \\
(0.000)\end{array}$ & 0.01 \\
\hline Cash-flow/total assets $(t-1)$ & $\begin{array}{c}-0.9105^{*} * * \\
(0.000)\end{array}$ & 0.03 & $\begin{array}{c}-0.9385 * * * \\
(0.000)\end{array}$ & 0.05 \\
\hline Loan interest spread & $\begin{array}{c}-1.1015^{* * *} * \\
(0.000)\end{array}$ & 0.03 & $\begin{array}{c}-1.1257 * * * \\
(0.000)\end{array}$ & 0.04 \\
\hline $\log (G D P)$ & $\begin{array}{c}0.0153 * * \\
(0.037)\end{array}$ & 0.01 & $\begin{array}{c}0.0120 * * \\
(0.029)\end{array}$ & 0.01 \\
\hline \multicolumn{5}{|l|}{ Supply of bank loans } \\
\hline Tangible fixed assets/total assets $(t-1)$ & $\begin{array}{c}1.3263^{* * * *} \\
(0.000)\end{array}$ & 0.01 & $\begin{array}{c}1.3529 * * * \\
(0.000)\end{array}$ & 0.01 \\
\hline Age of the firm & $\begin{array}{c}0.3418 * * * \\
(0.000)\end{array}$ & 0.01 & $\begin{array}{c}0.3602 * * * \\
(0.000)\end{array}$ & 0.01 \\
\hline Banks' market power (Lerner index) & $\begin{array}{c}-0.7096^{* *} \\
(0.014)\end{array}$ & 0.05 & $\begin{array}{c}-0.6472 * * * \\
(0.028)\end{array}$ & 0.01 \\
\hline Loan interest spread & $\begin{array}{c}1.0244 * * * \\
(0.000)\end{array}$ & 0.04 & $\begin{array}{c}1.3307 * * * \\
(0.000)\end{array}$ & 0.05 \\
\hline Default risk & $\begin{array}{l}0.0014 \\
(0.847)\end{array}$ & 0.00 & $\begin{array}{l}0.0019 \\
(0.787)\end{array}$ & 0.00 \\
\hline $\log (G D P)$ & $\begin{array}{c}0.0730^{* * * *} \\
(0.001)\end{array}$ & 0.01 & $\begin{array}{c}0.0821 * * * \\
(0.001)\end{array}$ & 0.02 \\
\hline \multicolumn{5}{|l|}{ Extended supply (I): relationship lending } \\
\hline Length ( $n$. years relationship) & $\begin{array}{c}0.1628 * * * \\
(0.001) \\
\end{array}$ & 0.01 & $\begin{array}{c}0.1453^{* * * *} \\
(0.001) \\
\end{array}$ & 0.01 \\
\hline Single vs. multiple bank relationships & $\begin{array}{c}0.3157 * * * \\
(0.001) \\
\end{array}$ & 0.01 & $\begin{array}{c}0.3602 * * * \\
(0.001)\end{array}$ & 0.01 \\
\hline Tangible fixed assets/total assets(t-1)X Length & $\begin{array}{c}1.2397 * * * \\
(0.001) \\
\end{array}$ & 0.01 & $\begin{array}{c}1.2201 \text { *** } \\
(0.001) \\
\end{array}$ & 0.01 \\
\hline \multicolumn{5}{|l|}{ Extended supply (II): Main bank characteristic, securitization issues and firm size type } \\
\hline Main bank issuance of ABS (ABS issuance/total loans)t-1 & $\begin{array}{c}0.1465 * * * \\
(0.001)\end{array}$ & 0.01 & $\begin{array}{c}0.1173 * * * \\
(0.001)\end{array}$ & 0.01 \\
\hline Main bank issuance of covered bonds (covered bonds issuance over total loans)t-1 & $\begin{array}{c}0.7071 \text { *** } \\
(0.001)\end{array}$ & 0.01 & $\begin{array}{c}0.5817 * * * \\
(0.001)\end{array}$ & 0.01 \\
\hline Dummy (1993-2006 vs. 2007-2008) & $\begin{array}{c}-0.1093 * * \\
(0.034) \\
\end{array}$ & 0.01 & $\begin{array}{c}-0.1624 * * \\
(0.027) \\
\end{array}$ & 0.01 \\
\hline $\begin{array}{l}\text { Main bank issuance of ABS (ABS issuance/total loans)t-1 X Dummy (1993-2007 vs. 2007- } \\
\text { 2008) }\end{array}$ & - & - & $\begin{array}{c}0.0113^{* *} \\
(0.025) \\
\end{array}$ & 0.01 \\
\hline $\begin{array}{l}\text { Main bank issuance of covered bonds (covered bonds issuance over total loans)t-1 X } \\
\text { Dummy (1993-2006 vs. 2007-2008) }\end{array}$ & - & - & $\begin{array}{c}-0.3158 * * \\
(0.015)\end{array}$ & 0.01 \\
\hline Main bank size & $\begin{array}{l}0.0095 \\
(0.263) \\
\end{array}$ & 0.02 & $\begin{array}{l}0.0162 \\
(0.275) \\
\end{array}$ & 0.01 \\
\hline Main bank cost-to-income ratio & $\begin{array}{c}-0.1763 * * \\
(0.025) \\
\end{array}$ & 0.01 & $\begin{array}{c}-0.1909 * * \\
(0.028) \\
\end{array}$ & 0.01 \\
\hline Main bank (0: commercial bank; 1 : savings bank) & $\begin{array}{c}0.0548 * * \\
(0.015) \\
\end{array}$ & 0.02 & $\begin{array}{c}0.0471 * * \\
(0.014)\end{array}$ & 0.02 \\
\hline Type of firm (0: large firm; $1: S M E)$ & $\begin{array}{c}-0.0853 * * * \\
(0.003)\end{array}$ & 0.02 & $\begin{array}{c}-0.0713 * * * \\
(0.003)\end{array}$ & 0.02 \\
\hline Reciprocal of total assets in the loan demand equation & $\begin{array}{c}360115.0 * * * \\
(0.000)\end{array}$ & 1465.4 & $\begin{array}{c}382552.4^{* * *} \\
(0.000)\end{array}$ & 1342.4 \\
\hline Reciprocal of total assets in the loan supply equation & $\begin{array}{c}251326.4^{* * * *} \\
(0.000)\end{array}$ & 2312.8 & $\begin{array}{c}274620.8^{* * * *} \\
(0.000)\end{array}$ & 2653.9 \\
\hline S.D. of the disturbance in demand equation & $\begin{array}{c}1.2268^{* * * *} \\
(0.000)\end{array}$ & 0.01 & $\begin{array}{c}1.2385 * * * \\
(0.000)\end{array}$ & 0.01 \\
\hline S.D. of the disturbance in supply equation & $\begin{array}{c}0.3675 * * * \\
(0.000)\end{array}$ & 0.01 & $\begin{array}{c}0.3487 * * * \\
(0.000)\end{array}$ & 0.01 \\
\hline Correlation coefficient between both disturbances & $\begin{array}{c}0.4619 * * * \\
(0.000)\end{array}$ & 0.02 & $\begin{array}{c}0.5214 * * * \\
(0.000)\end{array}$ & 0.03 \\
\hline Log likelihood & \multicolumn{2}{|c|}{129308} & \multicolumn{2}{|c|}{154662} \\
\hline Percentage of borrowing constrained firms & \multicolumn{2}{|c|}{$29.38 \%$} & \multicolumn{2}{|c|}{$30.02 \%$} \\
\hline Coincidence in the classification of firms as constrained (relative to Table 3, (I)) & \multicolumn{2}{|c|}{$88.2 \%$} & \multicolumn{2}{|c|}{$89.4 \%$} \\
\hline Observations & \multicolumn{2}{|c|}{326,332} & \multicolumn{2}{|c|}{326,332} \\
\hline Number of firms & \multicolumn{2}{|c|}{56,752} & \multicolumn{2}{|c|}{56,752} \\
\hline
\end{tabular}

$*, * * . * * *$ : Statistically significant at $10 \%, \% \%$ and $1 \%$ level, respectively 


\begin{tabular}{|c|c|c|c|c|}
\hline \multicolumn{5}{|c|}{$\begin{array}{l}\text { TABLE 6. ESTIMATED PARAMETERS OF THE DISEQUILIBRIUM MODEL. ROBUSTNESS TEST } \\
\text { BETWEEN SECURITIZATION AND BANK CHARACTERISTICS (LIQUIDITY \& OWNERSHIP) } \\
\text { Switching regression model estimated by full information maximum likelihood (FIML) } \\
\text { p-values in parenthesis Standard errors are clustered at the regional level }\end{array}$} \\
\hline \multirow[b]{2}{*}{ Demand for bank loans } & \multicolumn{2}{|c|}{ (I) } & \multicolumn{2}{|c|}{ (II) } \\
\hline & Coefficient & Std. Error & Coefficient & Std. Error \\
\hline Sales/total assets $(t-1)$ & $\begin{array}{c}01628 * * * \\
(0.000)\end{array}$ & 0.01 & $\begin{array}{c}0.2215^{* * *} \\
(0.000)\end{array}$ & 0.01 \\
\hline Cash-flow/total assets (t-1) & $\begin{array}{c}-0.8329 * * * \\
(0.000)\end{array}$ & 0.03 & $\begin{array}{c}-0.9120 * * * \\
(0.000)\end{array}$ & 0.04 \\
\hline Loan interest spread & $\begin{array}{c}-1.0118^{* * * *} \\
(0.000)\end{array}$ & 0.03 & $\begin{array}{c}-1.1163 * * * \\
(0.000) \\
\end{array}$ & 0.04 \\
\hline $\log (G D P)$ & $\begin{array}{c}0.0162^{* *} \\
(0.028)\end{array}$ & 0.01 & $\begin{array}{c}0.0118 * * \\
(0.020)\end{array}$ & 0.01 \\
\hline \multicolumn{5}{|l|}{ Supply of bank loans } \\
\hline Tangible fixed assets/total assets(t- 1$)$ & $\begin{array}{c}1.2719 * * * \\
(0.000)\end{array}$ & 0.01 & $\begin{array}{c}1.3516^{* * * *} \\
(0.000)\end{array}$ & 0.01 \\
\hline Age of the firm & $\begin{array}{c}0.3114 * * * \\
(0.000)\end{array}$ & 0.01 & $\begin{array}{c}0.3028^{* * * *} \\
(0.000)\end{array}$ & 0.01 \\
\hline Banks' market power (Lerner index) & $\begin{array}{c}-0.7052^{* *} \\
(0.018)\end{array}$ & 0.05 & $\begin{array}{c}-0.64705^{* * * *} \\
(0.020)\end{array}$ & 0.01 \\
\hline Loan interest spread & $\begin{array}{c}1.1573 * * * \\
(0.000)\end{array}$ & 0.05 & $\begin{array}{c}1.3245^{* * * *} \\
(0.000) \\
\end{array}$ & 0.06 \\
\hline Default risk & $\begin{array}{l}0.0029 \\
(0.608)\end{array}$ & 0.00 & $\begin{array}{l}0.0005 \\
(0.797) \\
\end{array}$ & 0.00 \\
\hline $\log (G D P)$ & $\begin{array}{c}0.0758 * * * \\
(0.001)\end{array}$ & 0.01 & $\begin{array}{c}0.0826^{* * *} \\
(0.001)\end{array}$ & 0.02 \\
\hline \multicolumn{5}{|l|}{ Extended supply (I): relationship lending } \\
\hline Length (n. years relationship) & $\begin{array}{c}0.1280 * * * \\
(0.001)\end{array}$ & 0.01 & $\begin{array}{c}0.1254^{* * *} \\
(0.001)\end{array}$ & 0.01 \\
\hline Single vs. multiple bank relationships & $\begin{array}{c}0.3743^{* * *} \\
(0.001)\end{array}$ & 0.01 & $\begin{array}{c}0.3513^{* * *} \\
(0.001)\end{array}$ & 0.01 \\
\hline Tangible fixed assets/total assets( $t-1) X$ Length & $\begin{array}{c}1.1629 * * * \\
(0.001)\end{array}$ & 0.01 & $\begin{array}{c}1.227 * * * \\
(0.001) \\
\end{array}$ & 0.01 \\
\hline \multicolumn{5}{|l|}{ Extended supply (II): Main bank characteristic, securitization issues and firm size type } \\
\hline Main bank issuance of ABS (ABS issuance/total loans)t-1 & $\begin{array}{c}0.1375^{* * *} \\
(0.001)\end{array}$ & 0.01 & $\begin{array}{c}0.1203^{* * * *} \\
(0.001)\end{array}$ & 0.01 \\
\hline Main bank issuance of covered bonds (covered bonds issuance over total loans)t-1 & $\begin{array}{c}0.7138^{* * * *} \\
(0.001)\end{array}$ & 0.01 & $\begin{array}{c}0.6627 * * * \\
(0.001)\end{array}$ & 0.01 \\
\hline Main bank liquidity ratio dummy (0: low liquidity; 1 : high liquidity) & $\begin{array}{c}0.029 * * * \\
(0.001) \\
\end{array}$ & 0.01 & & \\
\hline Main bank ownership (0: commercial bank; 1: savings bank) & ( & - & $\begin{array}{c}0.049 \\
(0.124)\end{array}$ & 0.04 \\
\hline $\begin{array}{l}\text { Main bank issuance of } A B S \text { (ABS issuance/total loans)t-1 X Main bank liquidity ratio dummy (0: low } \\
\text { liquidity; } 1 \text { : high liquidity) }\end{array}$ & $\begin{array}{c}0.0114 * * * \\
(0.001)\end{array}$ & 0.01 & - & - \\
\hline $\begin{array}{l}\text { Main bank issuance of covered bonds (covered bonds issuance over total loans)t-1 X Main bank liquidity } \\
\text { ratio dummy (0: low liquidity; 1: high liquidity) }\end{array}$ & $\begin{array}{l}0.0624 \\
(0.180) \\
\end{array}$ & 0.01 & - & - \\
\hline $\begin{array}{l}\text { Main bank issuance of ABS (ABS issuance/total loans)t-1 X Main bank ownership (0: commercial bank; } \\
\text { 1: savings bank) }\end{array}$ & - & - & $\begin{array}{l}0.0084 \\
(0.129) \\
\end{array}$ & 0.05 \\
\hline $\begin{array}{l}\text { Main bank issuance of covered bonds (covered bonds issuance over total loans)t-1 X Main bank } \\
\text { ownership (0: commercial bank; } 1: \text { savings bank) }\end{array}$ & - & - & $\begin{array}{c}0.0820^{* *} \\
(0.015)\end{array}$ & 0.01 \\
\hline 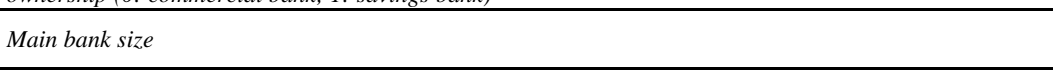 & $\begin{array}{l}0.0079 \\
(0.333)\end{array}$ & 0.02 & $\begin{array}{l}0.0126 \\
(0.242) \\
\end{array}$ & 0.01 \\
\hline Main bank cost-to-income ratio & $\begin{array}{c}-0.1662 * * \\
(0.027)\end{array}$ & 0.01 & $\begin{array}{c}-0.1638 * * \\
(0.027)\end{array}$ & 0.01 \\
\hline Type of firm (0: large firm; $1: S M E)$ & $\begin{array}{c}-0.0925^{* * *} \\
(0.005)\end{array}$ & 0.02 & $\begin{array}{c}-0.0720 * * * \\
(0.006)\end{array}$ & 0.02 \\
\hline Reciprocal of total assets in the loan demand equation & $\begin{array}{c}361128.4 * * * \\
(0.000)\end{array}$ & 1422.3 & $\begin{array}{c}358136.7^{* * *} \\
(0.000)\end{array}$ & 1305.4 \\
\hline Reciprocal of total assets in the loan supply equation & $\begin{array}{c}250426.7 * * * \\
(0.000)\end{array}$ & 2108.6 & $\begin{array}{c}261326.7^{* * * *} \\
(0.000)\end{array}$ & 2633.5 \\
\hline S.D. of the disturbance in demand equation & $\begin{array}{c}1.2408^{* * * *} \\
(0.000) \\
\end{array}$ & 0.01 & $\begin{array}{c}1.1407 * * * \\
(0.000) \\
\end{array}$ & 0.01 \\
\hline S.D. of the disturbance in supply equation & $\begin{array}{c}0.3562 * * * \\
(0.000)\end{array}$ & 0.01 & $\begin{array}{c}0.3129^{* * *} \\
(0.000)\end{array}$ & 0.01 \\
\hline Correlation coefficient between both disturbances & $\begin{array}{c}0.4421 * * * \\
(0.000)\end{array}$ & 0.02 & $\begin{array}{c}0.5082 * * * \\
(0.000)\end{array}$ & 0.04 \\
\hline Log likelihood & \multicolumn{2}{|c|}{129328} & \multicolumn{2}{|c|}{154336} \\
\hline Percentage of borrowing constrained firms & \multicolumn{2}{|c|}{$29.20 \%$} & \multicolumn{2}{|c|}{$30.07 \%$} \\
\hline Coincidence in the classification of firms as constrained (relative to specification (I)) & \multicolumn{2}{|c|}{$88.1 \%$} & \multicolumn{2}{|c|}{$89.1 \%$} \\
\hline Observations & \multicolumn{2}{|c|}{326,332} & \multicolumn{2}{|c|}{326,332} \\
\hline Number of firms & \multicolumn{2}{|c|}{56,752} & \multicolumn{2}{|c|}{56,752} \\
\hline
\end{tabular}




\begin{tabular}{|c|c|c|c|c|c|}
\hline \multicolumn{6}{|c|}{$\begin{array}{l}\text { TABLE 7. ESTIMATED PARAMETERS OF THE DISEQUILIBRIUM MODEL. } \\
\text { ROBUSTNESS CHECK: MAIN BANKS HA VING A LOW VS. HIGH REAL ESTATE } \\
\text { EXPOSURE (2000-2008) } \\
\text { Switching regression model estimated by full information maximum likelihood (FIML) with bank and firm fixed effects } \\
\text { p-values in parenthesis (Standard errors are clustered at the regional level) }\end{array}$} \\
\hline \multirow[b]{2}{*}{ Demand for bank loans } & \multicolumn{2}{|c|}{$\begin{array}{l}\text { Low real estate } \\
\text { exposure }\end{array}$} & \multicolumn{2}{|c|}{$\begin{array}{l}\text { High real estate } \\
\text { exposure }\end{array}$} & \multirow{2}{*}{$\begin{array}{l}\text { Coefficient } \\
\text { differences (p- } \\
\text { values) }\end{array}$} \\
\hline & Coefficient & $\begin{array}{l}\text { Std. } \\
\text { Error }\end{array}$ & Coefficient & $\begin{array}{l}\text { Std. } \\
\text { Error }\end{array}$ & \\
\hline Sales/total assets $(t-1)$ & $\begin{array}{c}0.3105^{* * * *} \\
(0.000)\end{array}$ & 0.01 & $\begin{array}{c}0.2905^{* * * *} \\
(0.000)\end{array}$ & 0.01 & $0.011 * *$ \\
\hline Cash-flow/total assets $(t-1)$ & $\begin{array}{c}-0.8872 * * * \\
(0.000)\end{array}$ & 0.06 & $\begin{array}{c}-0.9226 * * * \\
(0.000)\end{array}$ & 0.04 & 0.120 \\
\hline Loan interest spread & $\begin{array}{c}-1.1154 * * * \\
(0.000)\end{array}$ & 0.03 & $\begin{array}{c}-1.1283 * * * \\
(0.000)\end{array}$ & 0.03 & 0.181 \\
\hline $\log (G D P)$ & $\begin{array}{l}0.0119 * * \\
(0.020)\end{array}$ & 0.01 & $\begin{array}{c}0.0124 * * \\
(0.024)\end{array}$ & 0.01 & 0.071 \\
\hline \multicolumn{6}{|l|}{ Supply of bank loans } \\
\hline Tangible fixed assets/total assets $(t-1)$ & $\begin{array}{c}1.1405^{* * * *} \\
(0.000)\end{array}$ & 0.01 & $\begin{array}{c}1.4013 * * * \\
(0.000)\end{array}$ & 0.01 & $0.016^{* *}$ \\
\hline Age of the firm & $\begin{array}{c}0.3163 * * * \\
(0.000)\end{array}$ & 0.01 & $\begin{array}{c}0.3704 * * \\
(0.000)\end{array}$ & 0.01 & $0.083 *$ \\
\hline Banks' market power (Lerner index) & $\begin{array}{c}-0.7128 * * * \\
(0.027)\end{array}$ & 0.01 & $\begin{array}{c}-0.7629 * * * \\
(0.015)\end{array}$ & 0.01 & 0.697 \\
\hline Loan interest spread & $\begin{array}{c}1.5519 * * * * \\
(0.000)\end{array}$ & 0.05 & $\begin{array}{c}1.4105^{* * * *} \\
(0.000)\end{array}$ & 0.04 & $0.068^{*}$ \\
\hline Default risk & $\begin{array}{l}0.0008 \\
(0.891)\end{array}$ & 0.00 & $\begin{array}{l}0.0017 \\
(0.725)\end{array}$ & 0.00 & 0.123 \\
\hline $\log (G D P)$ & $\begin{array}{c}0.0658 * * * \\
(0.001)\end{array}$ & 0.02 & $\begin{array}{c}0.0627 * * * * \\
(0.001)\end{array}$ & 0.02 & 0.360 \\
\hline \multicolumn{6}{|l|}{ Extended supply (I): relationship lending } \\
\hline Length ( $n$. years relationship) & $\begin{array}{c}0.1322 * * * \\
(0.001)\end{array}$ & 0.01 & $\begin{array}{c}0.1003 * * * \\
(0.001)\end{array}$ & 0.01 & $0.020 * *$ \\
\hline Single vs. multiple bank relationships & $\begin{array}{c}0.3428 * * * \\
(0.001)\end{array}$ & 0.01 & $\begin{array}{c}0.3626^{* * * *} \\
(0.001)\end{array}$ & 0.01 & $0.046^{* *}$ \\
\hline Tangible fixed assets/total assets(t-1)X Length & $\begin{array}{c}1.1827 * * * \\
(0.001)\end{array}$ & 0.01 & $\begin{array}{c}1.1153 * * * \\
(0.001) \\
\end{array}$ & 0.01 & $0.071^{*}$ \\
\hline \multicolumn{6}{|c|}{ Extended supply (II): Main bank characteristics and securitization issues } \\
\hline Main bank issuance of ABS (ABS issuance/total loans)t-1 & $\begin{array}{c}0.1540 * * * \\
(0.001)\end{array}$ & 0.01 & $\begin{array}{c}0.1284 * * * \\
(0.001)\end{array}$ & 0.01 & $0.013 * *$ \\
\hline $\begin{array}{l}\text { Main bank issuance of covered bonds (covered bonds issuance over } \\
\text { total loans)t-1 }\end{array}$ & $\begin{array}{c}0.8237 * * * \\
(0.001) \\
\end{array}$ & 0.01 & $\begin{array}{c}0.6026^{* * *} \\
(0.001) \\
\end{array}$ & 0.01 & $0.004 * * *$ \\
\hline Dummy (2000-2006 vs. 2007-2008) & $\begin{array}{c}-0.1075^{* *} \\
(0.017)\end{array}$ & 0.01 & $\begin{array}{c}-0.1494 * * \\
(0.024)\end{array}$ & 0.01 & $0.017 * *$ \\
\hline $\begin{array}{l}\text { Main bank issuance of ABS (ABS issuance/total loans)t-1 X Dummy } \\
(2000-2006 \mathrm{vs.} 2007-2008)\end{array}$ & $\begin{array}{c}-0.2261 * * \\
(0.010)\end{array}$ & 0.01 & $\begin{array}{c}-0.3513^{* *} \\
(0.011)\end{array}$ & 0.01 & $0.010^{* *}$ \\
\hline $\begin{array}{l}\text { Main bank issuance of covered bonds (covered bonds issuance over } \\
\text { total loans)t-1 X Dummy (2000-2006 vs. 2007-2008) }\end{array}$ & $\begin{array}{c}0.0163 * * \\
(0.024)\end{array}$ & 0.01 & $\begin{array}{c}0.0135^{* *} \\
(0.025)\end{array}$ & 0.01 & $0.013^{* *}$ \\
\hline Main bank size & $\begin{array}{l}0.0140 \\
(0.293)\end{array}$ & 0.02 & $\begin{array}{l}0.0152 \\
(0.210)\end{array}$ & 0.02 & 0.496 \\
\hline Main bank cost-to-income ratio & $\begin{array}{c}-0.1905 * * \\
(0.023)\end{array}$ & 0.01 & $\begin{array}{c}-0.1672 * * \\
(0.027)\end{array}$ & 0.01 & $0.015^{* *}$ \\
\hline Reciprocal of total assets in the loan demand equation & $\begin{array}{c}387215.2 * * * \\
(0.000)\end{array}$ & 1284.9 & $\begin{array}{c}362605.4^{* * * *} \\
(0.000)\end{array}$ & 1323.5 & \\
\hline Reciprocal of total assets in the loan supply equation & $\begin{array}{c}260115.6^{* * * *} \\
(0.000)\end{array}$ & 2160.2 & $\begin{array}{l}261305.7 * * * \\
(0.000)\end{array}$ & 2395.7 & \\
\hline S.D. of the disturbance in demand equation & $\begin{array}{c}1.2705^{* * *} \\
(0.000)\end{array}$ & 0.01 & $\begin{array}{l}1.2165^{* * * *} \\
(0.000)\end{array}$ & 0.01 & \\
\hline S.D. of the disturbance in supply equation & $\begin{array}{l}0.3205^{* * * *} \\
(0.000)\end{array}$ & 0.01 & $\begin{array}{l}0.3173 * * * \\
(0.000)\end{array}$ & 0.01 & \\
\hline Correlation coefficient between both disturbances & $\begin{array}{l}0.5116^{* * * *} \\
(0.000) \\
\end{array}$ & 0.03 & $\begin{array}{l}0.5194 * * * \\
(0.000) \\
\end{array}$ & 0.04 & \\
\hline Log likelihood & \multicolumn{2}{|c|}{155209} & \multicolumn{2}{|c|}{152325} & \\
\hline Percentage of borrowing constrained firms & \multicolumn{2}{|c|}{$28.63 \%$} & \multicolumn{2}{|c|}{$33.18 \%$} & \\
\hline Observations & \multicolumn{2}{|c|}{163,166} & \multicolumn{2}{|c|}{163,166} & \\
\hline Number of firms & \multicolumn{2}{|c|}{28,376} & \multicolumn{2}{|c|}{28,376} & \\
\hline
\end{tabular}




\begin{tabular}{|c|c|c|c|c|c|c|}
\hline \multicolumn{7}{|c|}{$\begin{array}{l}\text { TABLE 8. ESTIMATED PARAMETERS OF THE DISEQUILIBRIUM MODEL. ROBUSTNESS TESTS: } \\
\text { SYNTHETIC ABS ISSUANCE (EXCLUDING LOAN SALES) (1993-2008) } \\
\text { Switching regression model estimated by full information maximum likelihood (FIML) with bank and firm fixed effects } \\
\text { p-values in parenthesis (Standard errors are clustered at the regional level) }\end{array}$} \\
\hline \multirow[b]{2}{*}{ Demand for bank loans } & \multicolumn{2}{|c|}{ (I) } & \multicolumn{2}{|c|}{ (II) } & \multicolumn{2}{|c|}{ (III) } \\
\hline & Coefficient & Std. Error & Coefficient & $\begin{array}{c}\text { Std. } \\
\text { Error }\end{array}$ & Coefficient & $\begin{array}{c}\text { Std. } \\
\text { Error }\end{array}$ \\
\hline Sales/total assets $(t-1)$ & $\begin{array}{c}0.3158^{* * * *} \\
(0.000)\end{array}$ & 0.01 & $\begin{array}{c}0.3203^{* * *} \\
(0.000)\end{array}$ & 0.01 & $\begin{array}{c}0.3025^{* * *} \\
(0.000)\end{array}$ & 0.01 \\
\hline Cash-flow/total assets(t-1) & $\begin{array}{c}-0.9035 * * * \\
(0.000) \\
\end{array}$ & 0.03 & $\begin{array}{c}-0.8926^{* * *} * \\
(0.000) \\
\end{array}$ & 0.06 & $\begin{array}{c}-0.9042 * * * \\
(0.000)\end{array}$ & 0.05 \\
\hline Loan interest spread & $\begin{array}{c}-1.1205^{* * * *} \\
(0.000)\end{array}$ & 0.04 & $\begin{array}{c}-1.1385 * * * * \\
(0.000) \\
\end{array}$ & 0.03 & $\begin{array}{c}-1.1395 * * * \\
(0.000) \\
\end{array}$ & 0.03 \\
\hline $\log (G D P)$ & $\begin{array}{c}0.0134 * * \\
(0.037)\end{array}$ & 0.01 & $\begin{array}{c}0.0134 * * \\
(0.014)\end{array}$ & 0.01 & $\begin{array}{c}0.0118^{* *} \\
(0.026)\end{array}$ & 0.01 \\
\hline \multicolumn{7}{|l|}{ Supply of bank loans } \\
\hline Tangible fixed assets/total assets( $t-1)$ & $\begin{array}{c}1.4526^{* * * *} \\
(0.000)\end{array}$ & 0.01 & $\begin{array}{c}1.3013^{* * *} \\
(0.000)\end{array}$ & 0.01 & $\begin{array}{c}1.3219^{* * *} \\
(0.000)\end{array}$ & 0.01 \\
\hline Age of the firm & $\begin{array}{c}0.3010^{\text {**** }} \\
(0.000)\end{array}$ & 0.01 & $\begin{array}{c}0.3690^{* * * *} \\
(0.000)\end{array}$ & 0.01 & $\begin{array}{c}0.3610^{* * *} \\
(0.000) \\
\end{array}$ & 0.01 \\
\hline Banks' market power (Lerner index) & $\begin{array}{c}-0.7109^{* *} \\
(0.032)\end{array}$ & 0.04 & $\begin{array}{c}-0.7037 * * \\
(0.024)\end{array}$ & 0.01 & $\begin{array}{c}-0.7406^{* * *} * \\
(0.020) \\
\end{array}$ & 0.01 \\
\hline Loan interest spread & $\begin{array}{c}1.0726^{* * * *} \\
(0.000)\end{array}$ & 0.04 & $\begin{array}{c}1.4304 * * * \\
(0.000)\end{array}$ & 0.04 & $\begin{array}{c}1.4115^{* * *} \\
(0.000)\end{array}$ & 0.04 \\
\hline Default risk & $\begin{array}{l}0.0014 \\
(0.826)\end{array}$ & 0.00 & $\begin{array}{l}0.0014 \\
(0.804) \\
\end{array}$ & 0.00 & $\begin{array}{l}0.0011 \\
(0.867)\end{array}$ & 0.00 \\
\hline $\log (G D P)$ & $\begin{array}{c}0.0718^{* * * *} \\
(0.001)\end{array}$ & 0.02 & $\begin{array}{c}0.0814 * * * \\
(0.001)\end{array}$ & 0.02 & $\begin{array}{c}0.0856^{* * *} \\
(0.001)\end{array}$ & 0.02 \\
\hline \multicolumn{7}{|l|}{ Extended supply (I): relationship lending } \\
\hline Length ( $n$. years relationship) & $\begin{array}{c}0.1234^{* * * *} \\
(0.001)\end{array}$ & 0.01 & $\begin{array}{c}0.1205^{* * *} \\
(0.001)\end{array}$ & 0.01 & $\begin{array}{c}0.1034 * * * \\
(0.001)\end{array}$ & 0.01 \\
\hline Single vs. multiple bank relationships & $\begin{array}{c}0.3428^{* * * *} \\
(0.001)\end{array}$ & 0.01 & $\begin{array}{c}0.3503^{* * *} \\
(0.001) \\
\end{array}$ & 0.01 & $\begin{array}{c}-0.3495 * * * \\
(0.001) \\
\end{array}$ & 0.01 \\
\hline Tangible fixed assets/total assets(t-1) X Length & $\begin{array}{c}1.2105^{* * * *} \\
(0.001)\end{array}$ & 0.01 & $\begin{array}{c}1.2194 * * * \\
(0.001)\end{array}$ & 0.01 & $\begin{array}{c}1.1422 * * * \\
(0.001)\end{array}$ & 0.01 \\
\hline \multicolumn{7}{|l|}{ Extended supply (II): Main bank characteristics and securitization issues } \\
\hline Main bank issuance of synthetic ABS (synthetic ABS issuance/total loans)t-1 & $\begin{array}{c}0.1210^{* *} \\
(0.001) \\
\end{array}$ & 0.01 & $\begin{array}{c}0.1207^{* *} \\
(0.001) \\
\end{array}$ & 0.01 & $\begin{array}{c}0.1019 * * \\
(0.001) \\
\end{array}$ & 0.01 \\
\hline $\begin{array}{l}\text { Main bank issuance of covered bonds (covered bonds issuance over total loans)t- } \\
1\end{array}$ & $\begin{array}{c}0.7119^{* * *} \\
(0.001)\end{array}$ & 0.01 & $\begin{array}{c}0.7113 * * * \\
(0.001)\end{array}$ & 0.01 & $\begin{array}{c}0.6231 * * * \\
(0.001)\end{array}$ & 0.01 \\
\hline Dummy (1993-2006 vs. 2007-2008) & & & $\begin{array}{c}-0.1104^{* *} \\
(0.025) \\
\end{array}$ & 0.01 & $\begin{array}{c}-0.1470^{* *} \\
(0.039) \\
\end{array}$ & 0.01 \\
\hline $\begin{array}{l}\text { Main bank issuance of synthetic ABS (synthetic ABS issuance/total loans)t-1 X } \\
\text { Dummy (1993-2006 vs. 2007-2008) }\end{array}$ & - & - & $\begin{array}{c}-0.3321 * * \\
(0.014) \\
\end{array}$ & 0.01 & 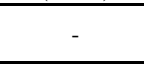 & - \\
\hline $\begin{array}{l}\text { Main bank issuance of covered bonds (covered bonds issuance over total loans)t- } \\
1 \text { X Dummy (1993-2006 vs. 2007-2008) }\end{array}$ & - & - & $\begin{array}{c}0.0117 * * \\
(0.028) \\
\end{array}$ & 0.01 & - & - \\
\hline $\begin{array}{l}\text { Main bank issuance of synthetic ABS ( synthetic ABS issuance/total loans)t-1 X } \\
\text { Dummy (1993-2007 vs. 2008) }\end{array}$ & - & - & - & - & $\begin{array}{c}-0.3045^{* *} \\
(0.011) \\
\end{array}$ & 0.01 \\
\hline $\begin{array}{l}\text { Main bank issuance of covered bonds (covered bonds issuance over total loans)t- } \\
1 \text { Dummy (1993-2007 vs.2008) }\end{array}$ & - & - & - & - & $\begin{array}{c}0.0134 * * \\
(0.022) \\
\end{array}$ & 0.01 \\
\hline Main bank size & $\begin{array}{l}0.0114 \\
(0.162) \\
\end{array}$ & 0.02 & $\begin{array}{l}0.0153 \\
(0.209) \\
\end{array}$ & 0.02 & $\begin{array}{l}0.0161 \\
(0.301) \\
\end{array}$ & 0.02 \\
\hline Main bank cost-to-income ratio & $\begin{array}{c}-0.1926 * * \\
(0.024)\end{array}$ & 0.01 & $\begin{array}{c}-0.1512^{* *} \\
(0.027)\end{array}$ & 0.01 & $\begin{array}{c}-0.1613^{* *} \\
(0.032)\end{array}$ & 0.01 \\
\hline Reciprocal of total assets in the loan demand equation & $\begin{array}{c}372044.6^{* * * *} \\
(0.000)\end{array}$ & 1433.5 & $\begin{array}{c}387224.1 * * * \\
(0.000)\end{array}$ & 1319.6 & $\begin{array}{c}372553.4 * * * \\
(0.000) \\
\end{array}$ & 1373.7 \\
\hline Reciprocal of total assets in the loan supply equation & $\begin{array}{c}261744.4^{* * * *} \\
(0.000) \\
\end{array}$ & 2243.0 & $\begin{array}{c}274086.0^{* * * *} \\
(0.000)\end{array}$ & 2615.2 & $\begin{array}{c}276227.5^{* * * *} \\
(0.000)\end{array}$ & 2523.0 \\
\hline S.D. of the disturbance in demand equation & $\begin{array}{c}1.2893^{* * *} \\
(0.000) \\
\end{array}$ & 0.01 & $\begin{array}{c}1.2539^{* * * *} \\
(0.000) \\
\end{array}$ & 0.01 & $\begin{array}{c}1.2406^{* * * *} \\
(0.000)\end{array}$ & 0.01 \\
\hline S.D. of the disturbance in supply equation & $\begin{array}{c}0.3127^{* * * * *} \\
(0.000)\end{array}$ & 0.01 & $\begin{array}{c}0.3853^{* * * *} \\
(0.000) \\
\end{array}$ & 0.01 & $\begin{array}{c}0.3117 * * * \\
(0.000) \\
\end{array}$ & 0.01 \\
\hline Correlation coefficient between both disturbances & $\begin{array}{c}0.4363^{* * * *} \\
(0.000) \\
\end{array}$ & 0.03 & $\begin{array}{c}0.5150 * * * \\
(0.000) \\
\end{array}$ & 0.03 & $\begin{array}{c}0.5026^{* * *} \\
(0.000) \\
\end{array}$ & 0.03 \\
\hline Log likelihood & \multicolumn{2}{|c|}{129052} & \multicolumn{2}{|c|}{154311} & \multicolumn{2}{|c|}{151407} \\
\hline Percentage of borrowing constrained firms & \multicolumn{2}{|c|}{$29.16 \%$} & \multicolumn{2}{|c|}{$30.19 \%$} & \multicolumn{2}{|c|}{$30.63 \%$} \\
\hline Coincidence in the classification of firms as constrained (relative to Table 3, (I)) & \multicolumn{2}{|c|}{$89.2 \%$} & \multicolumn{2}{|c|}{$91.4 \%$} & \multicolumn{2}{|c|}{$91.5 \%$} \\
\hline Observations & \multicolumn{2}{|c|}{326,332} & \multicolumn{2}{|c|}{326,332} & \multicolumn{2}{|c|}{326,332} \\
\hline Number of firms & \multicolumn{2}{|c|}{56,752} & \multicolumn{2}{|c|}{56,752} & \multicolumn{2}{|c|}{56,752} \\
\hline
\end{tabular}


FIGURE 1. LENDING TO FIRMS IN SPAIN (yearly growth rates)

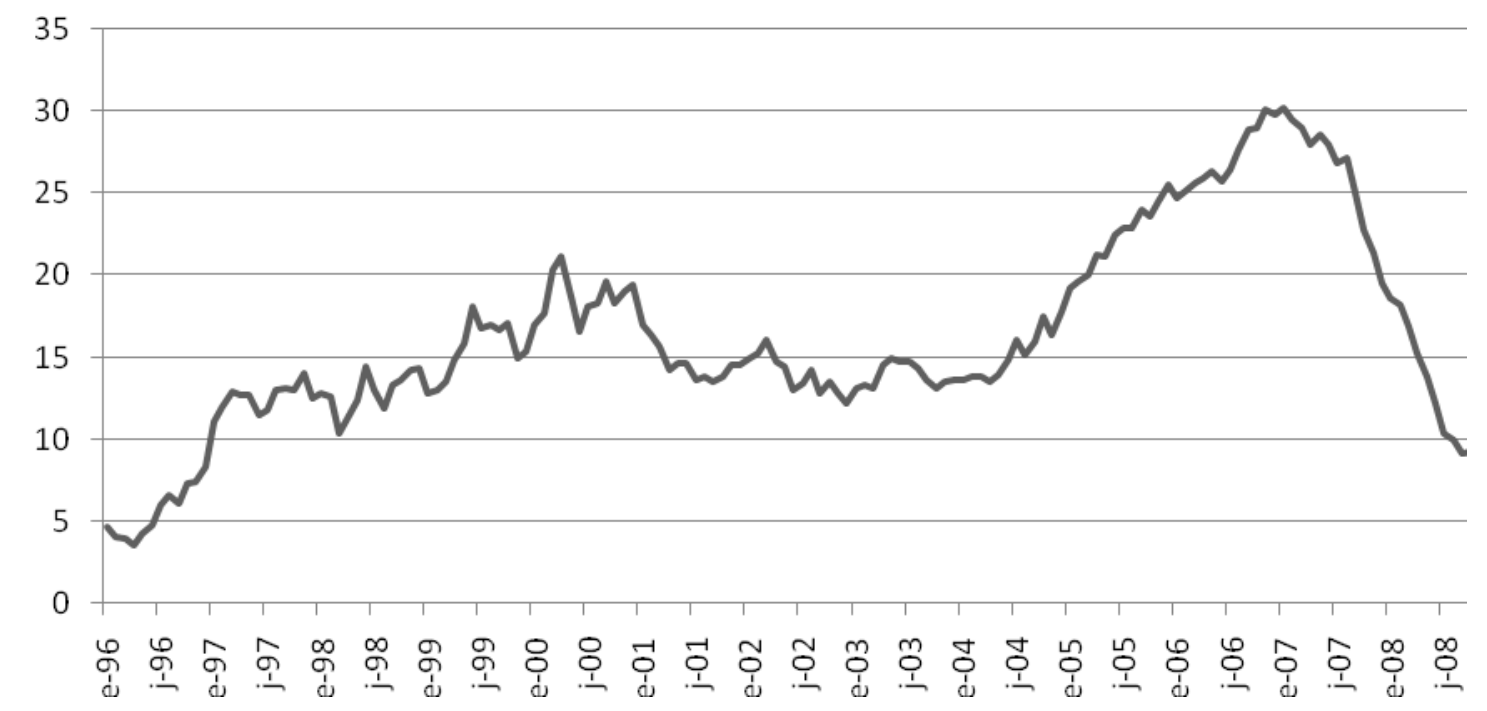

Source: Bank of Spain

FIGURE 2. COVERED BONDS AND ABS SECURITIZATION IN SPAIN (19992008)

Stock data. Euro million.

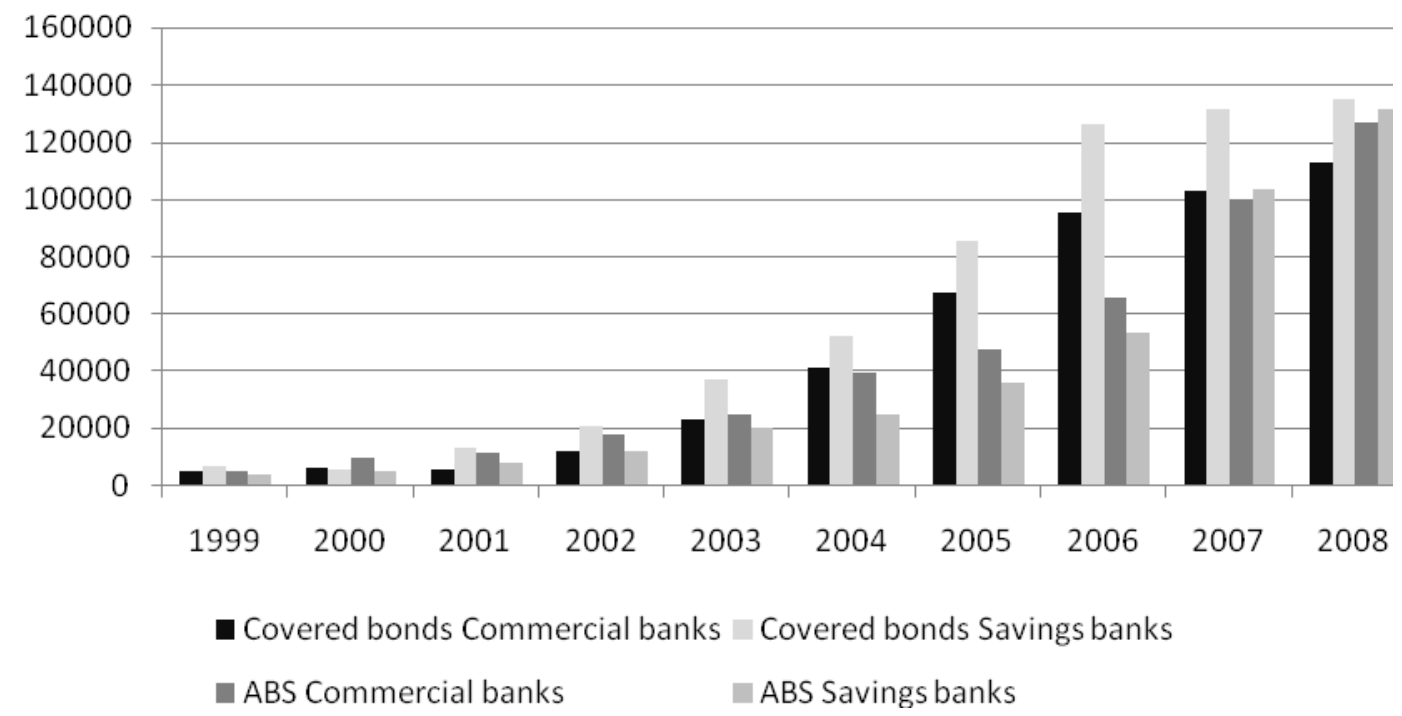

Source: Dealogic and AIAF (Asociación de Intermediarios de Activos Financieros) 
FIGURE 3. CONSTRAINED FIRMS AND RELATIONSHIP LENDING

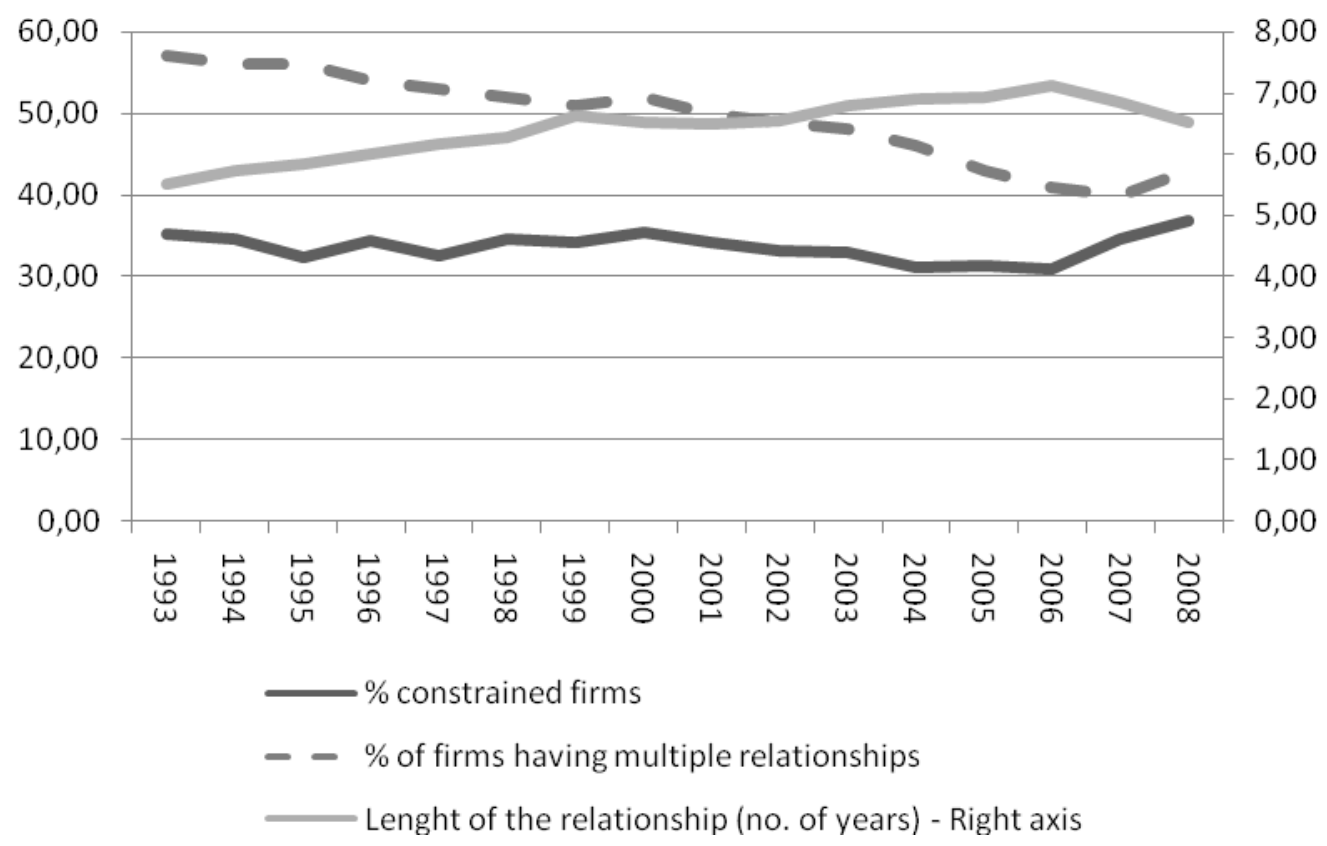

Source: Own estimations from SABI and Bankscope data

\section{FIGURE 4. CONSTRAINED FIRMS AND SECURITIZATION}

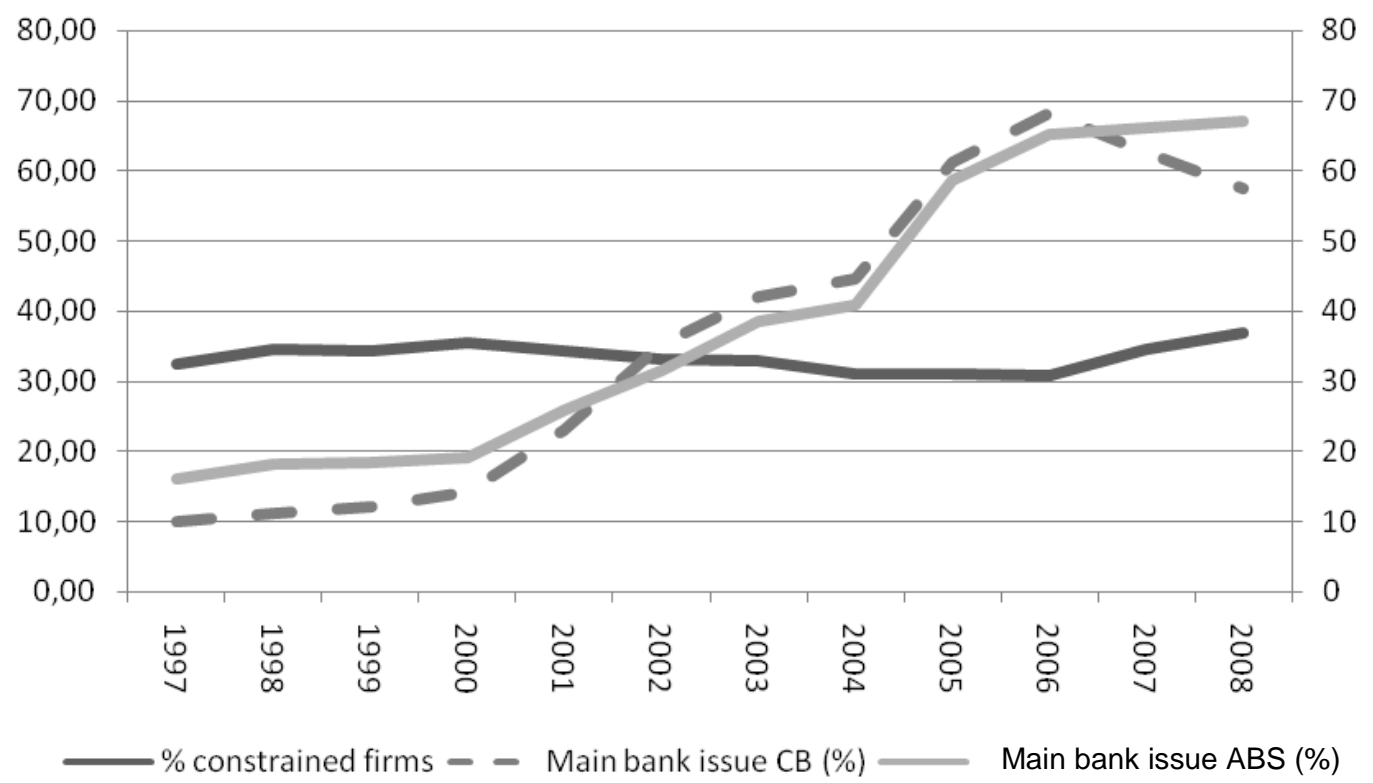

Source: Own estimations from SABI and Bankscope data 